\title{
Article
}

\section{Alkali-Activated Materials as Catalysts for Water Purification}

\author{
Anne Heponiemi *(D), Janne Pesonen (D), Tao Hu (D) and Ulla Lassi (D) \\ Research Unit of Sustainable Chemistry, University of Oulu, P.O. Box 4300, FI-90014 Oulu, Finland; \\ janne.pesonen@oulu.fi (J.P.); tao.hu@oulu.fi (T.H.); ulla.lassi@oulu.fi (U.L.) \\ * Correspondence: anne.heponiemi@oulu.fi
}

check for

updates

Citation: Heponiemi, A.; Pesonen, J.;

$\mathrm{Hu}, \mathrm{T}$; Lassi, U. Alkali-Activated Materials as Catalysts for Water Purification. Catalysts 2021, 11, 664. https://doi.org/10.3390/catal 11060664

Academic Editor: Roberto Fiorenza

Received: 7 May 2021

Accepted: 22 May 2021

Published: 23 May 2021

Publisher's Note: MDPI stays neutral with regard to jurisdictional claims in published maps and institutional affiliations.

Copyright: (c) 2021 by the authors. Licensee MDPI, Basel, Switzerland. This article is an open access article distributed under the terms and conditions of the Creative Commons Attribution (CC BY) license (https:// creativecommons.org/licenses/by/ $4.0 /)$.

\begin{abstract}
In this study, novel and cost-effective alkali-activated materials (AAMs) for catalytic applications were developed by using an industrial side stream, i.e., blast furnace slag (BFS). AAMs can be prepared from aluminosilicate precursors under mild conditions (room temperature using non-hazardous chemicals). AAMs were synthesized by mixing BFS and a $50 \mathrm{wt} \%$ sodium hydroxide $(\mathrm{NaOH})$ solution at different $\mathrm{BFS} / \mathrm{NaOH}$ ratios. The pastes were poured into molds, followed by consolidation at 20 or $60^{\circ} \mathrm{C}$. As the active metal, Fe was impregnated into the prepared AAMs by ion exchange. The prepared materials were examined as catalysts for the catalytic wet peroxide oxidation (CWPO) of a bisphenol A (BPA) aqueous solution. As-prepared AAMs exhibited a moderate surface area and mesoporous structure, and they exhibited moderate activity for the CWPO of BPA, while the iron ion-exchanged, BFS-based catalyst (Fe/BFS30-60) exhibited the maximum removal of BPA $(50 \%)$ during $3 \mathrm{~h}$ of oxidation at $\mathrm{pH} 3.5$ at $70{ }^{\circ} \mathrm{C}$. Therefore, these new, inexpensive, AAM-based catalysts could be interesting alternatives for catalytic wastewater treatment applications.
\end{abstract}

Keywords: alkali-activated material; geopolymer; blast furnace slag; catalytic wet peroxide oxidation; Fe-catalyst; bisphenol A

\section{Introduction}

Alkali-activated materials (AAMs) are inorganic, amorphous compounds that contain $\left[\mathrm{SiO}_{4}\right]^{4-}$ and $\left[\mathrm{AlO}_{4}\right]^{5-}$, which can be prepared by using aluminosilicates in addition to hydroxides, carbonates, or silicates of alkali and alkaline earth metals. The calcium content affects the AAM structure; therefore, materials with a low Ca content comprise a three-dimensional, highly interconnected aluminosilicate framework (also known as a geopolymer) [1], while those with a high Ca content comprise a cross-linked and non-cross linked structure that resembles that of tobermorite [2]. The use of AAMs, and especially geopolymers, has been investigated in the building industry as a more environmentfriendly alternative to Portland cement, due to their chemical and physical stability [3-5], as well as in more advanced applications, such as adsorbents for the removal of impurities from wastewater [6-9] and composite materials [4]. Moreover, owing to the fact that the structure of AAMs is similar to that of zeolites, their use as catalytic materials can also be exploited. Compared with the synthesis of zeolites, that of AAMs can be performed at ambient pressure and room temperature, using cost-effective raw materials (kaolin clay or industrial waste, such as fly ash), making AAMs fascinating, environment-friendly alternatives to commercial zeolite. Only a few years ago, Sazama et al. reported the synthesis of AAM-based catalysts [10] by the modification of metakaolin geopolymers for the catalytic reduction of nitrogen oxides by ammonia, as well as the total oxidation of volatile hydrocarbons. Furthermore, metakaolin-based geopolymers and steel slagcontaining AAMs also have been examined for photocatalytic applications [11,12] and biodiesel production [13]. Therefore, AAMs are interesting alternatives as catalysts, as well as for water-phase applications like catalytic wet peroxide oxidation (CWPO).

Bisphenol A (BPA) is an estrogenic compound commonly used in the production of polycarbonate plastic and epoxy resin, which are further utilized in several daily-use 
plastic products, such as drinking bottles, containers, thermal paper, etc. [14]. BPA can be spread into water bodies during the manufacturing process, and also from daily-use plastic products. Due to its endocrine disrupting character for humans and environment [15], the removal of it from wastewaters is essential. Several techniques, such as activated sludge treatment [16], membrane bioreactors [17], and sorption [18,19] have been used for the removal of BPA from wastewaters. In addition of these, advanced oxidation processes (AOPs) have been effectively used for the oxidation of BPA in wastewaters [20]. Techniques like photolysis [21] and ozonation [22], as well as hybrid processes like $\mathrm{UV} / \mathrm{H}_{2} \mathrm{O}_{2}$ [23], $\mathrm{UV} / \mathrm{O}_{3}$ [24], $\mathrm{UV} / \mathrm{TiO}_{2}$ [25], and $\mathrm{O}_{2} / \mathrm{H}_{2} \mathrm{O}_{2}$ [26], have been successfully used for the oxidation of BPA. In this study, one of AOPs, CWPO, is studied for the removal of BPA from water. In CWPO, hydrogen peroxide is used as an oxidizing agent to decompose organic compounds from wastewater. Transition metals, typically $\mathrm{Fe}$ and $\mathrm{Cu}$, are used as catalysts in the reaction to decompose hydrogen peroxide to active hydroxyl radicals (Equation (1)) [27].

$$
\mathrm{M}^{\mathrm{n}+}+\mathrm{H}_{2} \mathrm{O}_{2} \rightarrow \mathrm{M}^{(\mathrm{n}+1)+}+\mathrm{HO}^{-}+\mathrm{HO}^{\bullet}
$$

The formed hydroxyl radicals can further oxidize organic compounds, according to Equation (2):

$$
\mathrm{RH}+\mathrm{HO}_{2} \rightarrow \mathrm{R}^{\bullet}+\mathrm{H}_{2} \mathrm{O}_{2}
$$

To obtain the reduced form of the active metals, they must be dispersed on suitable supports [28,29]. Various materials have been used as supports in CWPO. Carbon-based materials, such as activated carbon [30], graphite, carbon black [31], carbon nanotubes [32], and biomass-based carbons [33], have been successfully used for the degradation of organics with CWPO. Moreover, zeolites $[34,35]$ and clay materials $[36,37]$ also have been applied as supports for $\mathrm{Fe}$ and $\mathrm{Cu}$; therefore, $\mathrm{AAMs}$ with a chemical composition similar to those of zeolites and clay minerals are interesting alternatives as carriers for use in CWPO.

However, for the use of industrial side streams as raw materials in a catalyst, the prepared material must exhibit stability, especially when the prepared material is used for water treatment applications. Typically, catalyst stability for photocatalytic experiments has been evaluated in consecutive tests [38] and by characterization of the used materials after experiments, e.g., by X-ray diffraction (XRD) and Fourier transform infrared spectroscopy (FTIR) $[39,40]$.

In this study, the industrial side stream from the steel industry, i.e., blast furnace slag (BFS), was applied as a raw material to produce cost-effective catalytic materials for water purification. Catalysts were prepared by mixing different ratios of $\mathrm{BFS}$ and $\mathrm{NaOH}$, followed by their consolidation at $20^{\circ} \mathrm{C}$ and $60^{\circ} \mathrm{C}$. Moreover, iron was impregnated as the active metal in the AAMs via ion exchange. The as-prepared materials were characterized, e.g., by XRD, and their surface area and catalytic activity were examined for the CWPO of a bisphenol A (BPA) aqueous solution. Particular attention has been focused on the stability of materials; therefore, the possible leaching of the main elements (such as $\mathrm{Ca}$, $\mathrm{Si}, \mathrm{Al}, \mathrm{Mg}$, and $\mathrm{Na}$ ) has been investigated before the CWPO of BPA under $2 \mathrm{MPa}$ and 150 ${ }^{\circ} \mathrm{C}$. Furthermore, the concentrations of the main elements of the as-prepared materials was analyzed after oxidation experiments from water samples, as well as those from the used catalysts.

\section{Results and Discussion}

In this section, the stability and characteristics, such as phase composition and specific surface area, of the prepared materials are discussed. In addition, the activity of AAMs for the CWPO of BPA is evaluated. The prepared materials were named according to their $\mathrm{NaOH}$ concentration and consolidation temperature (Section 3.1).

\subsection{Stability of Alkali-Activated Materials}

Table 1 lists the conductivity values of aqueous solutions after $4 \mathrm{~h}$ at $150{ }^{\circ} \mathrm{C}$ under an $\mathrm{N}_{2}$ atmosphere of $2 \mathrm{MPa}$ and an AAM concentration of $4 \mathrm{~g} / \mathrm{dm}^{3}$. 
Table 1. Conductivity of aqueous solutions after $4 \mathrm{~h}$ at $150{ }^{\circ} \mathrm{C}$ under an $\mathrm{N}_{2}$ atmosphere of $2 \mathrm{MPa}$ and AAM concentration of $4 \mathrm{~g} / \mathrm{dm}^{3}$.

\begin{tabular}{cc}
\hline AAM & Conductivity $[\boldsymbol{\mu S} / \mathrm{cm}]$ \\
\hline BFS & 533 \\
BFS17.5-20 & 252 \\
BFS17.5-60 & 332 \\
BFS20-20 & 320 \\
BFS20-60 & 288 \\
BFS25-20 & 191 \\
BFS25-60 & 166 \\
BFS30-20 & 204 \\
BFS30-60 & 195 \\
\hline
\end{tabular}

The conductivity values of aqueous solutions after $4 \mathrm{~h}$ of experiments were $200-300 \mu \mathrm{S} / \mathrm{cm}$; according to these values, the alkali activation of BFS stabilized the material. With the increase in the amount of $\mathrm{NaOH}$ in the sample, the conductivity of aqueous solutions decreased slightly. In addition, the curing temperature affected the conductivity, i.e., samples that were first cured at $60{ }^{\circ} \mathrm{C}$ for $24 \mathrm{~h}$ exhibited lower conductivity than those cured at room temperature.

Table 2 lists the concentrations of $\mathrm{Ca}, \mathrm{Si}$, and $\mathrm{Al}$ in aqueous solutions after $4 \mathrm{~h}$ at $150{ }^{\circ} \mathrm{C}$, under an $\mathrm{N}_{2}$ atmosphere of $2 \mathrm{MPa}$ and an AAM concentration of $4 \mathrm{~g} / \mathrm{dm}^{3}$.

Table 2. $\mathrm{Ca}, \mathrm{Si}$, and $\mathrm{Al}$ concentrations of aqueous solutions after $4 \mathrm{~h}$ at $150^{\circ} \mathrm{C}$, under an $\mathrm{N}_{2}$ atmosphere of $2 \mathrm{MPa}$ and an AAM concentration of $4 \mathrm{~g} / \mathrm{dm}^{3}$.

\begin{tabular}{cccc}
\hline AAM & $\mathbf{C a}\left[\mathbf{m g} / \mathbf{d m}^{3}\right]$ & $\mathbf{S i}\left[\mathbf{m g} / \mathbf{d m}^{3}\right]$ & $\mathbf{A 1}\left[\mathbf{m g} / \mathbf{d m}^{3}\right]$ \\
\hline BFS17.5-20 & 29 & 16.0 & 2.6 \\
BFS17.5-60 & 15 & 8.5 & 1.3 \\
BFS20-20 & 20 & 9.6 & 1.8 \\
BFS20-60 & 22 & 8.1 & 2.3 \\
BFS25-20 & 34 & 7.7 & 3.5 \\
BFS25-60 & 23 & 9.9 & 2.8 \\
BFS30-20 & 27 & 12.0 & 4.9 \\
BFS30-60 & 31 & 11.0 & 4.3 \\
\hline
\end{tabular}

In addition to those of $\mathrm{Ca}, \mathrm{Si}$, and $\mathrm{Al}, \mathrm{Mg}$ and $\mathrm{Na}$ concentrations also were analyzed from water samples by inductively coupled plasma-optical emission spectroscopy (ICP-OES). However, the magnesium concentration was less than the detection limit $\left(\leq 0.1 \mathrm{mg} / \mathrm{dm}^{3}\right)$, and the maximum sodium concentration was $1 \mathrm{mg} / \mathrm{dm}^{3}$ after $4 \mathrm{~h}$ at $150{ }^{\circ} \mathrm{C}$ and an $\mathrm{N}_{2}$ atmosphere of $2 \mathrm{MPa}$. All of the samples exhibited almost the same $\mathrm{Ca}$ and $\mathrm{Si}$ concentrations. However, with the increase in the amount of $\mathrm{NaOH}$ in the samples, the leaching of aluminum increased. Clearly, alkali activation immobilized Al in the inorganic matrix, but basicity enhanced its dissolution [41]. Furthermore, curing at room temperature led to the enhanced dissolution of $\mathrm{Ca}$ and $\mathrm{Al}$ from AAMs. A curing temperature of $60^{\circ} \mathrm{C}$ has been found to be favorable for geopolymer preparation. MuñizVillarreal et al. [42] have reported that the optimum dissolution and formation of hydroxy species and oligomers, as well as further polymerization or condensation, occur at $60^{\circ} \mathrm{C}$. Therefore, with the increase in the curing temperature of the BFS-based AAMs, the leaching of $\mathrm{Ca}, \mathrm{Si}$, and $\mathrm{Al}$ decreased. Thus, based on these stability tests, AAMs that are first cured at $60{ }^{\circ} \mathrm{C}$ for $24 \mathrm{~h}$ are further characterized by $\mathrm{XRD}$, diffuse-reflectance infrared Fourier transform spectroscopy (DRIFTS), field emission scanning electron microscope with energydispersive X-ray spectroscopy (FESEM-EDS), ICP-OES, and surface area techniques, as well as being examined for the CWPO of a BPA aqueous solution. 


\subsection{Characterization of AAMs}

Table 3 lists the results of the Brunauer-Emmett-Teller (BET) surface areas of the prepared AAMs.

Table 3. BET-specific surface areas (SSA) and pore volumes (PV) of AAMs.

\begin{tabular}{ccc}
\hline Sample & SSA $\left[\mathbf{m}^{2} / \mathbf{g}\right]$ & PV $\left[\mathbf{m}^{2} / \mathbf{g}\right]$ \\
\hline BFS & 1.21 & 0.003 \\
BFS17.5-20 & 19.5 & 0.081 \\
BFS17.5-60 & 13.2 & 0.062 \\
BFS20-20 & 14.6 & 0.077 \\
BFS20-60 & 14.8 & 0.083 \\
BFS25-20 & 11.0 & 0.047 \\
BFS25-60 & 23.7 & 0.119 \\
BFS30-20 & 26.5 & 0.112 \\
BFS30-60 & 27.3 & 0.162 \\
Fe/BFS17.5-60 & 38.0 & 0.120 \\
Fe/BFS30-60 & 52.0 & 0.162 \\
\hline
\end{tabular}

The specific surface area of BFS was negligible, while alkali activation led to the increased surface area of all samples (Table 3). Samples prepared by using the highest amount of $\mathrm{NaOH}$ exhibited the highest specific surface area, as well as the highest pore volume. Clearly, a low Si/Na ratio favored the formation of a porous structure in the samples. Sindhunata et al. [43] have reported the highest pore volume for fly-ash-based geopolymers at a $\mathrm{SiO}_{2} / \mathrm{Na}_{2} \mathrm{O}$ ratio $<1$. Moreover, the samples cured at $60{ }^{\circ} \mathrm{C}$ for $24 \mathrm{~h}$ exhibited a slightly higher specific surface area, and hence a higher pore volume, than those prepared at room temperature. The higher curing temperature promoted the removal of excess water from the material structure, which in turn increased the porosity of samples further. Furthermore, higher curing temperatures $\left(>50^{\circ} \mathrm{C}\right)$ have been reported to particularly increase the amount of mesopores in the material [43].

As can be observed from the surface area results, no significant differences between the AAMs were observed. Therefore, to examine the effect of the Na concentration of samples on the catalytic behavior, samples with the lowest and highest $\mathrm{Na}$ concentration (BFS17.5-60 and BFS30-60) were selected as support materials for Fe catalysts. Surprisingly, the surface areas of the Fe catalysts were greater than those of the BFS17.5-60 and BFS30-60 pure supports (Table 3 ). This result was related to the calcination performed for Fe catalysts. During heat treatment, excess water and carbon dioxide of the support material, and well as traces of Fe salt, evaporated from the AAM structure, enabling the increase in the specific surface area [44]. In addition, the calcination of Fe catalysts led to the decomposition of hydrotalcite (Figure 1, XRD results), which also affected the surface area of materials [44]. Furthermore, as-prepared AAMs mainly exhibited a mesoporous structure (i.e., pore diameter between 2 and $50 \mathrm{~nm}$ ), with $10 \%$ of pores exhibiting a diameter of less than $2 \mathrm{~nm}$. However, by the addition of Fe to BFS17.5-60 and BFS30-60 via ion exchange, the number of mesopores decreased to $80 \%$, while micropores accounted for only a small percentage of the total pore volume. Moreover, macropores accounted for only $\sim 15 \%$ of the total pore volume in Fe/BFS17.5-60 and Fe/BFS30-60, while before Fe ion exchange, pores greater than $50 \mathrm{~nm}$ were not detected (i.e., heat treatment enhanced the formation of large pores). 


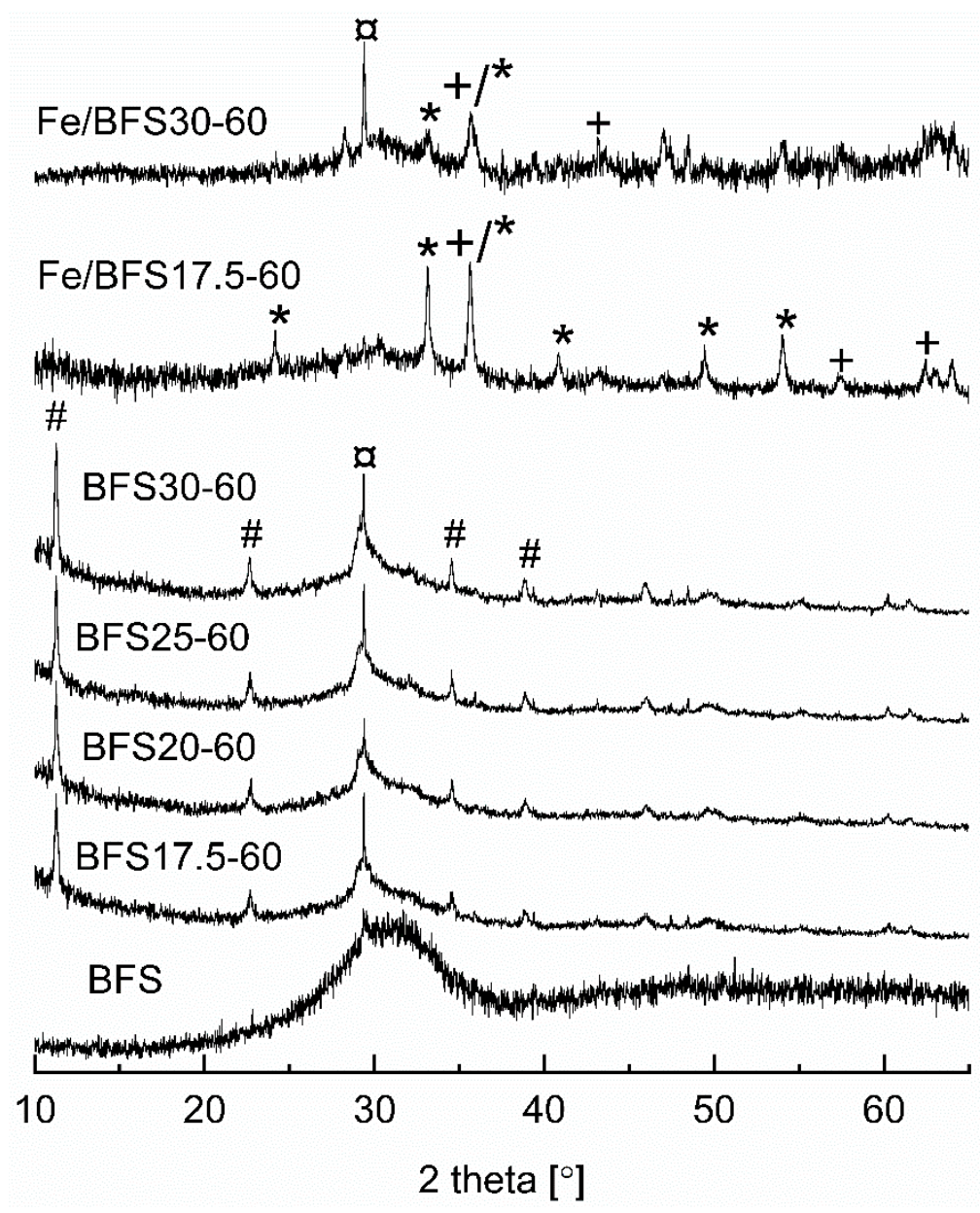

Figure 1. X-ray diffractograms of BFS raw material, supports, and Fe catalysts. (\#) ICDD file 00022-0700 ( $\mathrm{Mg}_{6} \mathrm{Al}_{2} \mathrm{CO}_{3}(\mathrm{OH})_{16} \cdot 4 \mathrm{H}_{2} \mathrm{O}$, hydrotalcite); (a) ICDD file 01-083-4609 $\left(\mathrm{CaCO}_{3}\right)$; $\left({ }^{*}\right)$ ICDD file 04-015-7029 $\left(\mathrm{Fe}_{2} \mathrm{O}_{3}\right)$; (+) ICDD file 04-008-8146 $\left(\mathrm{Fe}_{3} \mathrm{O}_{4}\right)$.

Figure 1 shows the X-ray diffractograms of the BFS raw material; BFS17.5-60, BFS20-60, BFS25-60, and BFS30-60 supports; and Fe/BFS17.5-60 and Fe/BFS30-60 catalysts. In the X-ray diffractogram of BFS, crystal peaks were not observed, but only one wide halo at $2 \theta$ between $22^{\circ}$ and $40^{\circ}$ was observed, which is characteristic of an amorphous material. After the alkali activation of BFS with $\mathrm{NaOH}$, peaks were observed at $2 \theta$ values of $11.3^{\circ}, 22.8^{\circ}$, $34.5^{\circ}$, and $38.6^{\circ}$ (denoted with \#), corresponding to hydrotalcite $\left(\mathrm{Mg}_{6} \mathrm{Al}_{2} \mathrm{CO}_{3}(\mathrm{OH})_{16} \cdot 4 \mathrm{H}_{2} \mathrm{O}\right.$ (ICDD file 00-022-0700)), and the high-intensity peak at $29.4^{\circ}$ corresponded to $\mathrm{CaCO}_{3}$ (ICDD file 01-083-4609). However, the broad "hump" observed at $2 \theta$ of $28-35^{\circ}$ was still present in the X-ray diffractograms of all supports, indicative of a partly amorphous structure. After the ion exchange of BFS17.5-60 and BFS30-60 with the Fe solution, the peaks observed at $2 \theta$ values of $24.1^{\circ}, 33.2^{\circ}, 35.6^{\circ}, 40.9^{\circ}, 49.5^{\circ}$, and $54.1^{\circ}$ (denoted by ${ }^{*}$ ) and at $35.7^{\circ}, 43.4^{\circ}, 57.4^{\circ}$, and $63.0^{\circ}$ (denoted by + ) revealed the presence of $\mathrm{Fe}_{2} \mathrm{O}_{3}$ (ICDD file 04-015-7029) and $\mathrm{Fe}_{3} \mathrm{O}_{4}$ (ICDD file 04-008-8146) phases, respectively. Owing to the heat treatment of Fe catalysts, hydrotalcite was decomposed [44], and peaks corresponding to hydrotalcite were not observed in the X-ray diffractograms of Fe/BFS17.5-60 and Fe/BFS30-60.

Figure 2 shows the DRIFT spectra of BFS, BFS17.5-60, BFS30-60, Fe/BFS17.5-60, and $\mathrm{Fe} / \mathrm{BFS30}$-60. In the DRIFT spectrum of the BFS raw material, only a few peaks were observed. The band at $\sim 1420 \mathrm{~cm}^{-1}$ corresponded to $\mathrm{Na}_{2} \mathrm{CO}_{3}$ [45], and the strong peak at $\sim 1110 \mathrm{~cm}^{-1}$ corresponded to pure silica [46]. 


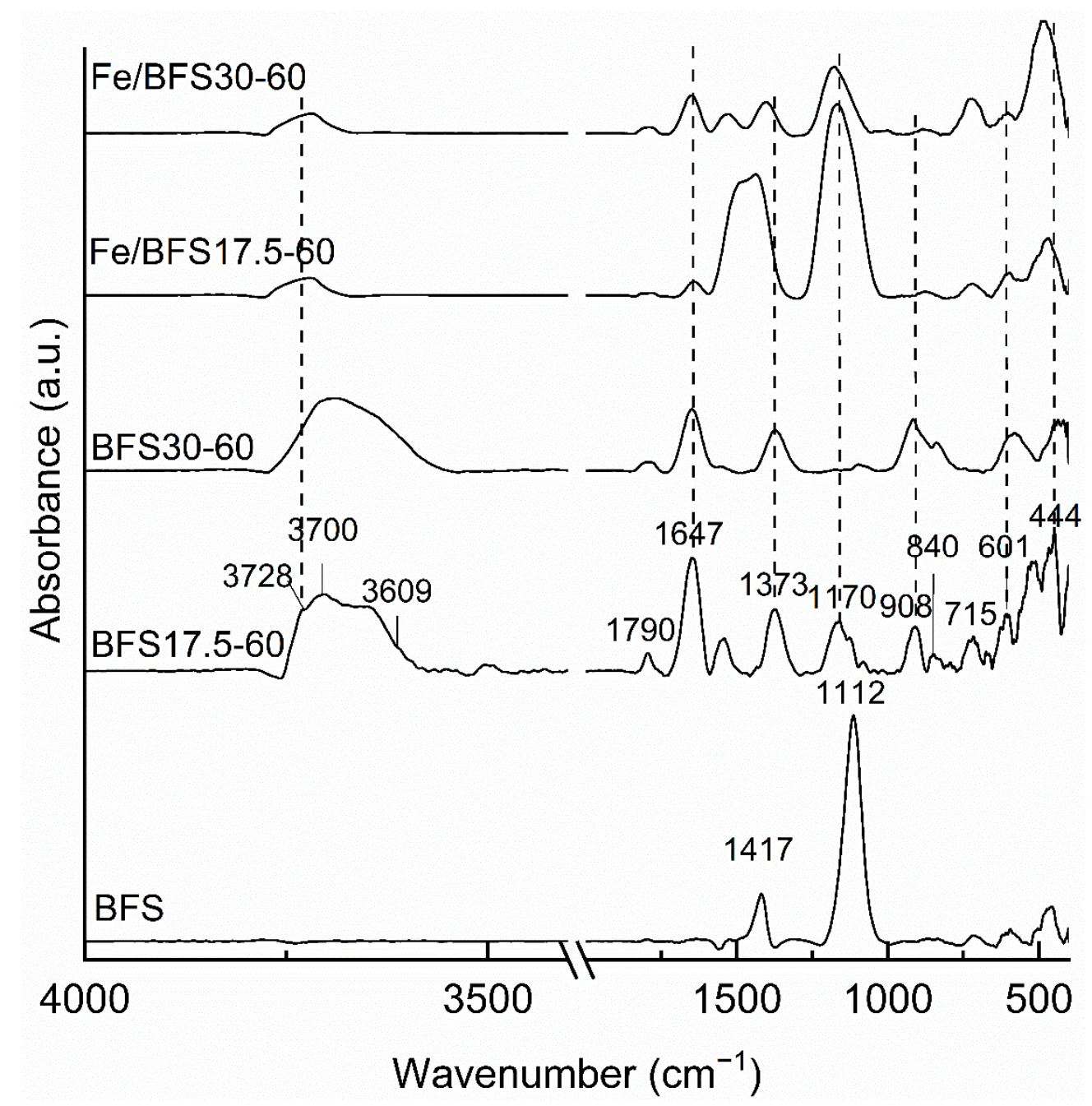

Figure 2. DRIFT spectra of BFS, BFS17.5-60, BFS30-60, Fe/BFS17.5-60, and Fe/BFS30-60 samples.

Alkali-activated samples exhibited several peaks in the analyzed region. The peak at $3730 \mathrm{~cm}^{-1}$ for BFS17.5-60 corresponded to silanol groups, which interact with other atoms - for example, in silanol nests [47] —and the absorption peak at $\sim 3700 \mathrm{~cm}^{-1}$ revealed the presence of four coordinated $\mathrm{Al}$ [48]. Moreover, the band at $3610 \mathrm{~cm}^{-1}$ for BFS17.5-60 corresponded to the bridging hydroxyl groups [49]. In the DRIFT spectra of Fe/BFS17.5-60 and $\mathrm{Fe} / \mathrm{BFS} 30-60$, the peak centers were shifted to higher wavenumbers than those for the samples without iron, probably due to calcination, and the absorption band corresponding to the silanol groups $\left(3730 \mathrm{~cm}^{-1}\right)$ disappeared by the introduction of iron into AAMs [47].

The absorbance bands for BFS17.5-60 and BFS30-60 were observed at 715, 840, 1373, and $1790 \mathrm{~cm}^{-1}$, corresponding to $\mathrm{CO}_{3}{ }^{2-}$-containing compounds [46]. Bands at 840 and $1790 \mathrm{~cm}^{-1}$ connected to $\mathrm{Na}_{2} \mathrm{CO}_{3}$, and the band at $715 \mathrm{~cm}^{-1}$ corresponded to $\mathrm{CaCO}_{3}$ [46], while that observed at $1373 \mathrm{~cm}^{-1}$ corresponded to hydrotalcite [50], which was also detected in the X-ray diffractograms of these samples (Figure 1). In the DRIFT spectra of $\mathrm{Fe} / \mathrm{BFS} 17.5-60$ and Fe/BFS30-60, these peaks were slightly shifted to higher wavenumbers, especially for the band corresponding to hydrotalcite, indicative of its decomposition as a result of heat treatment. Furthermore, the peak at $\sim 1650 \mathrm{~cm}^{-1}$ observed in all samples corresponded to the $\mathrm{H}-\mathrm{OH}$ stretching vibrations characteristic of absorbed water [51], the intensity of which slightly decreased due to the heat treatment of iron-containing samples.

All AAMs exhibited several bands corresponding to the $\mathrm{Al}$ and $\mathrm{Si}$ bonds. The bands at $435-483 \mathrm{~cm}^{-1}$ corresponded to the $\mathrm{Si}-\mathrm{O}-\mathrm{Si}$ and O-Si-O bending vibrations [52], while the absorption peak at $\sim 600 \mathrm{~cm}^{-1}$ revealed the presence of $\mathrm{Si}-\mathrm{O}-\mathrm{Si}$ and $\mathrm{Al}-\mathrm{O}-\mathrm{Si}$ symmetric stretching vibrations [53]. The band at $\sim 900 \mathrm{~cm}^{-1}$ in the spectra of BFS17.5-60 and BFS30-60 
corresponded to the $\mathrm{Si}-\mathrm{O}$ stretching and $\mathrm{Si}-\mathrm{OH}$ bending modes [53]. Moreover, the band at $\sim 1170 \mathrm{~cm}^{-1}$ corresponded to the $\mathrm{Si}-\mathrm{O}-\mathrm{Si}$ and $\mathrm{Al}-\mathrm{O}-\mathrm{Si}$ asymmetric stretching vibrations [53], and this band was broadened in the spectra of Fe/BFS17.5-60 and Fe/BFS30-60, due to the calcination of these samples [45]. According to [54-56], $\mathrm{Fe}_{2} \mathrm{O}_{3}$ and $\mathrm{Fe}_{3} \mathrm{O}_{4}$ species should exhibit IR vibrations at 550 and $780 \mathrm{~cm}^{-1}$ and 571 and $590 \mathrm{~cm}^{-1}$, respectively. However, owing to the overlap of the $\mathrm{Si}$ and $\mathrm{Al}$ vibrations in this wavenumber region, peaks corresponding to Fe cannot be observed in the DRIFT spectra of the prepared samples.

Table 4 lists the concentrations (as wt \%) of $\mathrm{Ca}, \mathrm{Si}, \mathrm{Al}, \mathrm{Mg}$, $\mathrm{Fe}$, and $\mathrm{Na}$ of BFS17.5-60, BFS30-60, Fe/BFS17.5-60, and Fe/BFS30-60, as determined by ICP-OES analysis.

Table 4. Metal concentrations (as wt \%) of selected samples, as determined by ICP-OES analysis.

\begin{tabular}{ccccccc}
\hline Sample & Ca & Si & $\begin{array}{c}\text { Al } \\
(\mathbf{w t ~ \% )}\end{array}$ & Mg & Fe & Na \\
\hline BFS17.5-60 & 23.3 & 14.7 & 4.34 & 5.32 & 0.70 & 0.24 \\
BFS30-60 & 21.9 & 14.4 & 4.17 & 5.07 & 1.86 & 0.29 \\
$\begin{array}{c}\text { Fe/BFS17.5- } \\
\text { 60 }\end{array}$ & 20.3 & 16.2 & 4.90 & 5.77 & 6.99 & 0.19 \\
$\begin{array}{c}\text { Fe/BFS30- } \\
\text { 60 }\end{array}$ & 20.0 & 15.1 & 4.58 & 5.49 & 4.95 & 0.19 \\
\hline
\end{tabular}

The Ca concentrations of the prepared samples were several times lower than those in $\mathrm{BFS}$, while the $\mathrm{Si}, \mathrm{Al}, \mathrm{Mg}$, and $\mathrm{Na}$ concentrations were about the same as those in the raw material (Table 5, experimental). The leaching of Ca probably occurred during the washing of the AAMs using deionized water. BFS contained $\sim 0.5 \mathrm{wt} \%$ iron, and ion exchange led to the increase in the iron concentration to $5-7 \mathrm{wt} \%$ for Fe/BFS30-60 and Fe/BFS17.5-60, respectively. The theoretical amount of iron by the employed impregnation method was $5.3 \mathrm{wt} \%$, indicating that ion exchange between BFS17.5-60 and the iron salt is slightly better than that between BFS30-60 and the iron salt.

Table 5. Elemental composition of the blast furnace slag as determined by ICP-OES analysis ${ }^{1}$.

\begin{tabular}{ccccccccccccc}
\hline \multicolumn{11}{c}{$[\mathbf{c t} \%]$} \\
\hline BFS & 28.70 & 16.30 & 5.00 & 4.87 & 1.44 & 0.60 & 0.58 & 0.53 & 0.50 & 0.28 & 0.06 & 0.04 \\
\hline
\end{tabular}

${ }^{1}$ Elements with wt $\%>0.01$ were reported.

Figure 3 shows the FESEM images of BFS, Fe/BFS17.5-60, and Fe/BFS30-60. AAMs clearly exhibited an irregular, non-crystalline shape (Figure $3 b, c$ ). According to EDS analysis, the $\mathrm{Al}$ and $\mathrm{Mg}$ concentrations were $\sim 5 \mathrm{wt} \%$, while on the Fe catalyst surface, the $\mathrm{Si}$ and $\mathrm{Ca}$ concentrations were a few percent less than those in the bulk, as determined by ICP-OES (Table 4).
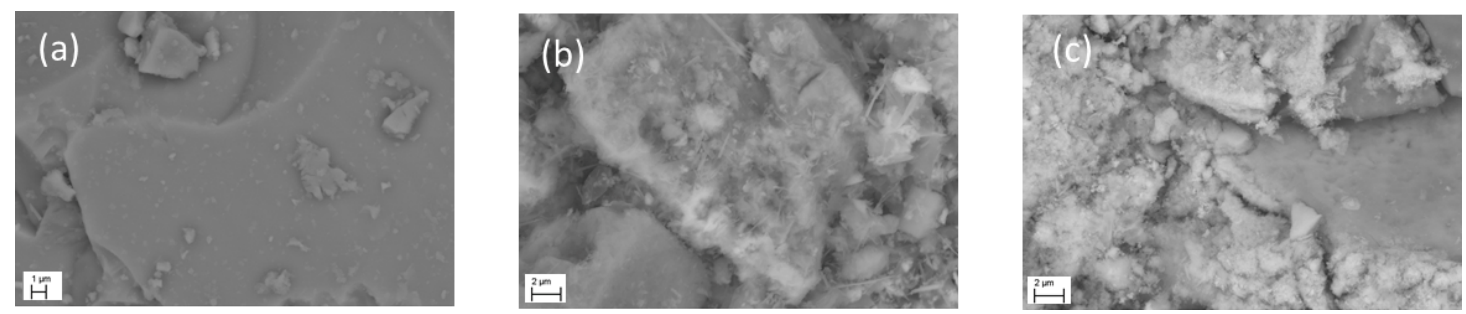

Figure 3. FESEM micrographs of BFS (a), Fe/BFS17.5-60 (b), and Fe/BFS30-60 (c). Dimensions in figures: $1 \mu \mathrm{m}(\mathbf{a})$ and $2 \mu \mathrm{m}$ $(\mathrm{b}, \mathrm{c})$. 


\subsection{Oxidation Experiments with $A A M s$}

The prepared AAMs, namely BFS17.5-60, BFS20-60, BFS25-60, and BFS30-60, which were first cured at $60^{\circ} \mathrm{C}$ for $24 \mathrm{~h}$, were examined for the CWPO of a BPA aqueous solution. Figure 4 shows the results of these experiments.

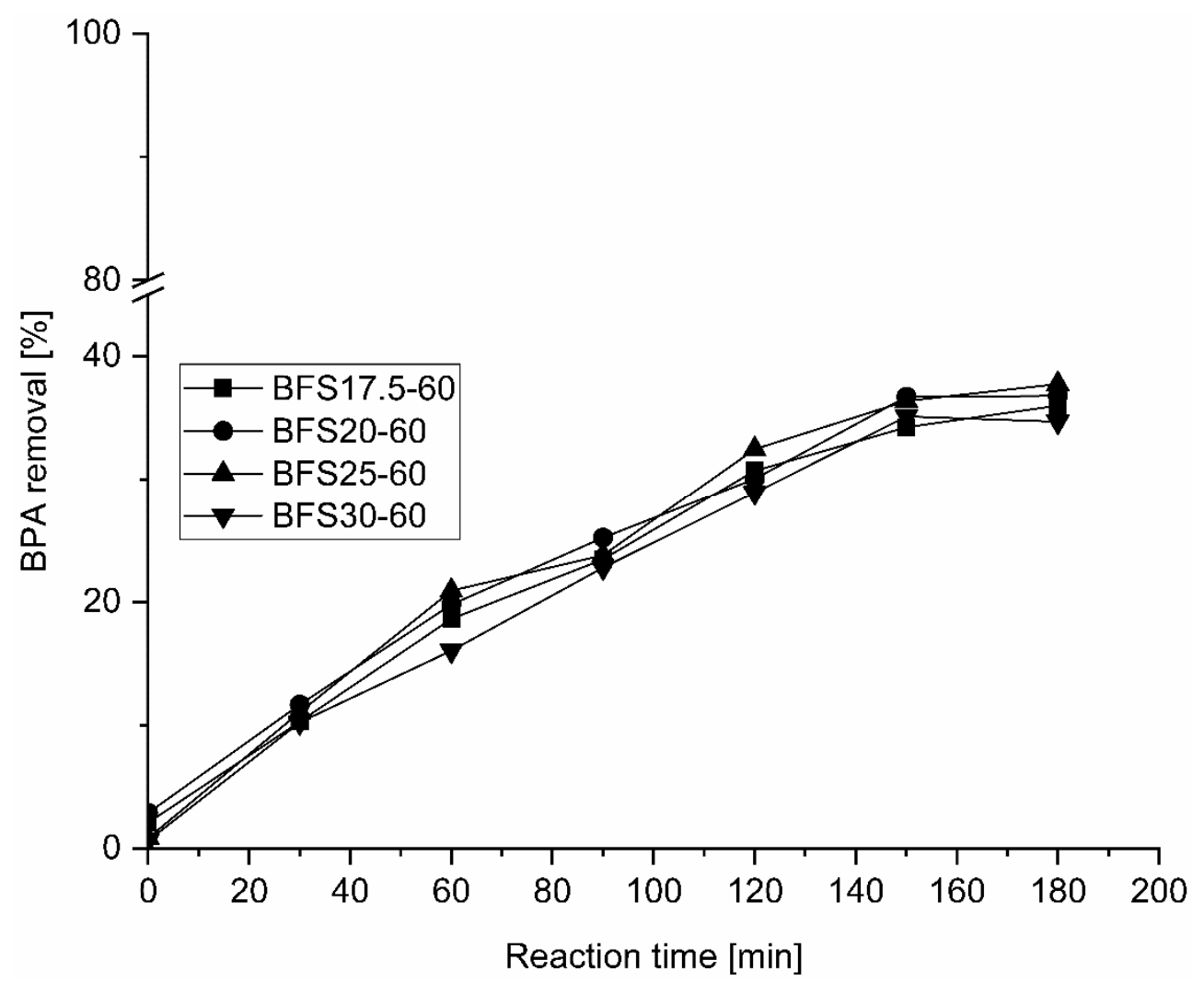

Figure 4. Removal of bisphenol A over AAMs as a function of the reaction time. Reaction conditions: concentration [c], $c[\mathrm{BPA}]=60 \mathrm{mg} / \mathrm{dm}^{3}, c\left[\mathrm{H}_{2} \mathrm{O}_{2}\right]=1.5 \mathrm{~g} / \mathrm{dm}^{3}, c$ catalyst $]=4 \mathrm{~g} / \mathrm{dm}^{3}$, temperature $[T]=50{ }^{\circ} \mathrm{C}$, initial $\mathrm{pH}(6-7)$.

Oxidation reactions were performed at $50{ }^{\circ} \mathrm{C}$ at an initial $\mathrm{pH}$ of $6-7$, a catalyst concentration of $4 \mathrm{~g} / \mathrm{dm}^{3}$, and $\mathrm{H}_{2} \mathrm{O}_{2}$ concentration of $1.5 \mathrm{~g} / \mathrm{dm}^{3}$. In the absence of a catalyst (not shown), only $\sim 10 \%$ of BPA removal was observed, while in the presence of AAMs, BPA removal of $35-39 \%$ after 180 min oxidation was observed. Oxidation proceeded during $2.5 \mathrm{~h}$ for all samples and stabilized for $3 \mathrm{~h}$. The oxidant $\mathrm{H}_{2} \mathrm{O}_{2}$ was added in batches; hence, the final addition was performed at $2 \mathrm{~h}$ sampling. The total organic carbon (TOC) was measured from the initial and final samples, and $27-31 \%$ of organics were removed. The dissolved oxygen (DO) concentration of the BPA samples changed from $\sim 9.5 \mathrm{mg} \mathrm{O} / \mathrm{O}_{2}$ to $8.1 \mathrm{mg} \mathrm{O}_{2} / \mathrm{dm}^{3}$ during $180 \mathrm{~min}$ oxidation, revealing that at the end of the run, oxygen is still present in the samples. Probably, the used reaction temperature $\left(50^{\circ} \mathrm{C}\right)$ was not sufficiently high for the effective decomposition of $\mathrm{H}_{2} \mathrm{O}_{2}$ to form active $\cdot \mathrm{OH}$ radicals. In several studies, a higher reaction temperature has been reported to enhance the degradation of $\mathrm{H}_{2} \mathrm{O}_{2}$, thereby enhancing pollutant removal [57-59].

As all of the AAMs exhibited similar activities for the removal of BPA, samples with the lowest and highest $\mathrm{NaOH}$ concentration were selected for further research. Iron was impregnated onto BFS17.5-60 and BFS30-60 samples by ion exchange (Section 3.1), and the prepared Fe catalysts were examined under different reaction conditions.

First, the effect of the addition of the active metal on BFS17.5-60 and BFS30-60 was examined at $50{ }^{\circ} \mathrm{C}$ at the initial $\mathrm{pH}$, and a catalyst loading of $4 \mathrm{~g} / \mathrm{dm}^{3}$. After $3 \mathrm{~h}$ oxidation, BPA removal of $42 \%$ and $45 \%$ for Fe/BFS17.5-60 and Fe/BFS30-60 were observed, respectively (Figure 5). Using the comparison of BPA removal over AAMs without the active metal (Figure 4), the addition of Fe led to the increased activity of both catalysts, namely 
BPA removal of $6 \%$ and $10 \%$ for BFS17.5-60 and BFS30-60, respectively. TOC removal after $3 \mathrm{~h}$ oxidation was at the same level for both catalysts compared to that over the pure supports (30\% and 33\% for Fe/BFS17.5-60 and Fe/BFS30-60, respectively). During oxidation, the DO concentration decreased slightly from $\sim 9 \mathrm{mg} / \mathrm{O}_{2} \mathrm{dm}^{3}$ to $6.2-6.6 \mathrm{mg} / \mathrm{O}_{2} \mathrm{dm}{ }^{3}$, indicating that hydrogen peroxide is not consumed completely in the runs. Therefore, $\mathrm{Fe} / \mathrm{BFS} 17.5-60$ and Fe/BFS30-60 were further examined at higher reaction temperatures.

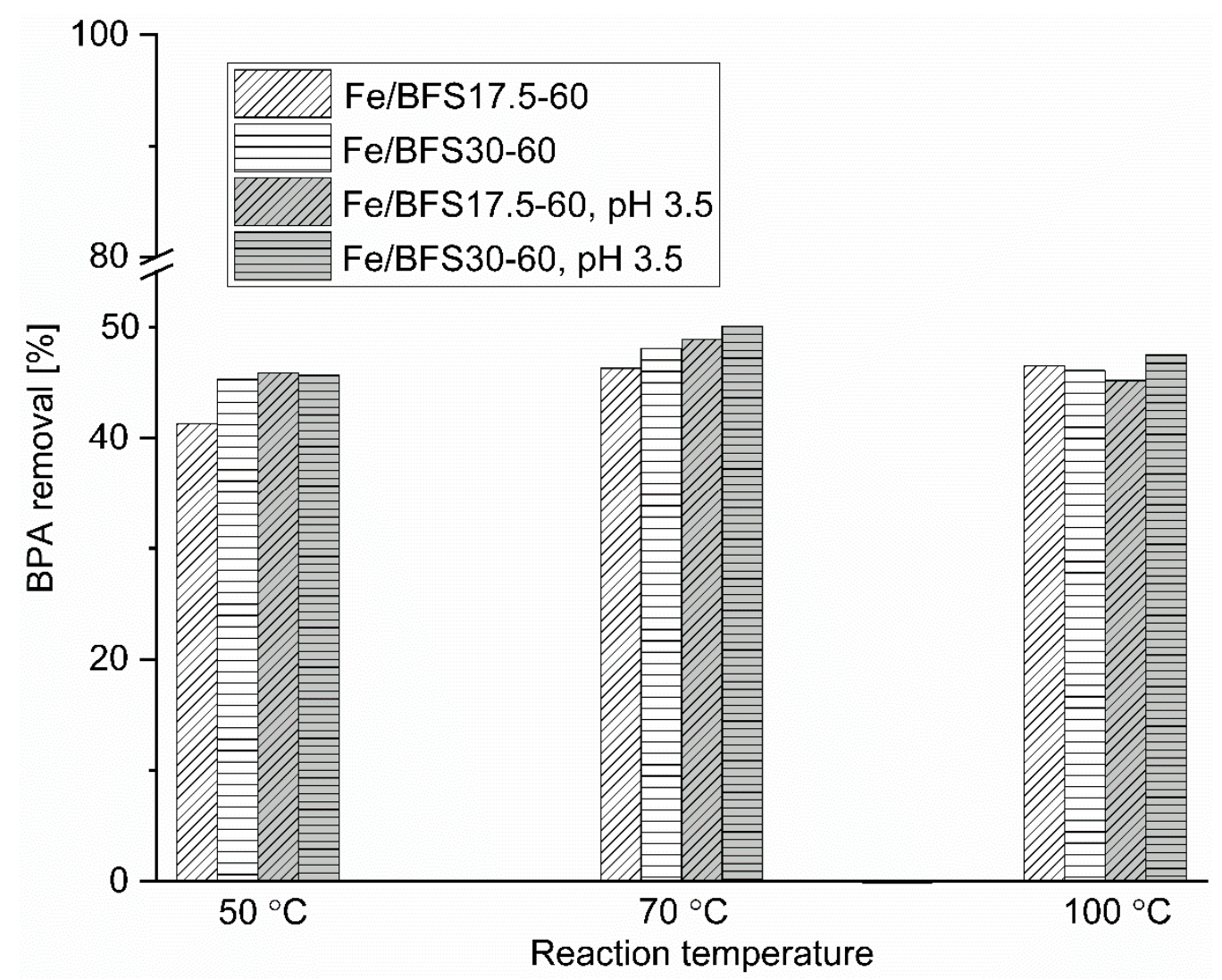

Figure 5. Bisphenol A removal at reaction temperatures of $50{ }^{\circ} \mathrm{C}, 70^{\circ} \mathrm{C}$, and $100{ }^{\circ} \mathrm{C}$ with the $\mathrm{Fe} / \mathrm{BFS} 17.5-60$ and Fe/BFS30-60 catalysts, at an initial $\mathrm{pH}$ of 3.5 , a reaction time of $3 \mathrm{~h},[\mathrm{BPA}]=60 \mathrm{mg} / \mathrm{dm}^{3}, c\left[\mathrm{H}_{2} \mathrm{O}_{2}\right]=1.5 \mathrm{~g} / \mathrm{dm}^{3}$, and $c[$ catalyst $]=4 \mathrm{~g} / \mathrm{dm}{ }^{3}$.

To investigate the effect of temperature on the CWPO of BPA over Fe/BFS17.5-60 and $\mathrm{Fe} / \mathrm{BFS} 30-60$, oxidation experiments were performed at $70{ }^{\circ} \mathrm{C}$ and $100{ }^{\circ} \mathrm{C}$ at the initial $\mathrm{pH}$ of the BPA aqueous solution. Typically, with the increase in the reaction temperature, the oxidation rate increases. Furthermore, the decomposition rate of $\mathrm{H}_{2} \mathrm{O}_{2}$ to active hydroxyl radicals also increases. A higher reaction temperature led to the improved degradation of BPA during $3 \mathrm{~h}$ oxidation, with the maximum of $5 \%$ over Fe/BFS17.5-60 at $70{ }^{\circ} \mathrm{C}$ (Figure 5). The increase in the reaction temperature to $100{ }^{\circ} \mathrm{C}$ did not affect BPA removal. During oxidation, the $\mathrm{DO}$ concentration decreased from $8.0 \mathrm{mg} / \mathrm{O}_{2} \mathrm{dm}^{3}$ to $5.7 \mathrm{mg} / \mathrm{O}_{2} \mathrm{dm}^{3}$ and from $\sim 10.0 \mathrm{mg} / \mathrm{O}_{2} \mathrm{dm}^{3}$ to $4.2 \mathrm{mg} / \mathrm{O}_{2} \mathrm{dm}^{3}$ at $70{ }^{\circ} \mathrm{C}$ and $100{ }^{\circ} \mathrm{C}$, respectively, revealing that hydrogen peroxide is consumed in the reaction. However, owing to the low degradation level of BPA at $100{ }^{\circ} \mathrm{C}$, hydrogen peroxide was probably decomposed directly to $\mathrm{H}_{2} \mathrm{O}$ without the formation of hydroxyl radicals.

Typically, homogeneous iron catalysts for CWPO (Fenton process) are used at a $\mathrm{pH}$ of $\sim 3$, which is known to be optimum for the decomposition of organic compounds [60]. The effect of $\mathrm{pH}$ on the degradation level of BPA was investigated at $\mathrm{pH} 3.5$, in addition to the initial $\mathrm{pH}(6-7)$ by using Fe/BFS17.5-60 and Fe/BFS30-60 catalysts. The effect of $\mathrm{pH}$ was examined at $50{ }^{\circ} \mathrm{C}, 70^{\circ} \mathrm{C}$, and $100{ }^{\circ} \mathrm{C}$. The $\mathrm{pH}$ of the BPA solution was adjusted to 3.5 using $2.0 \mathrm{M} \mathrm{HNO}_{3}$ before oxidation. At $50{ }^{\circ} \mathrm{C}$ and $\mathrm{pH} 3.5$, BPA removal increased by $5 \%$ over Fe/BFS17.5-60, while over Fe/BFS30-60, it was almost the same after $3 \mathrm{~h}$ 
oxidation compared to experiments performed at the initial $\mathrm{pH}$ of BPA (Figure 5). The $\mathrm{DO}$ concentration of the liquid samples was considerably higher (at the end of the run for $\mathrm{Fe} / \mathrm{BFS} 17.5-60,14 \mathrm{mg} / \mathrm{O}_{2} \mathrm{dm}^{3}$ ) than that after oxidation at the initial $\mathrm{pH}$. Therefore, acidic $\mathrm{pH}$ promotes the formation of hydroxyl radicals during the reaction. However, Fe catalysts did not exhibit considerably higher activity for BPA removal than that at the initial $\mathrm{pH}$, probably due to the basic surfaces of Fe/BFS17.5-60 and Fe/BFS30-60.

At pH 3.5 and $70{ }^{\circ} \mathrm{C}$ (Figure 5), the DO concentration was the same during tests compared to that in experiments at the initial $\mathrm{pH}$, and the $\mathrm{pH}$ change of the BPA solution led to an increase in BPA removal by only $3 \%$ and $2 \%$ over Fe/BFS17.5-60 and Fe/BFS30-60, respectively. At $100{ }^{\circ} \mathrm{C}$ and $\mathrm{pH} 3.5, \mathrm{BPA}$ removal after $3 \mathrm{~h}$ was around the same for both $\mathrm{Fe}$ catalysts compared with that observed at $100^{\circ} \mathrm{C}$ and at the initial $\mathrm{pH}$. However, notably, owing to the basicity of Fe catalysts, the $\mathrm{pH}$ of the BPA solution changed to basic during runs in all experiments. The decomposition of $\mathrm{H}_{2} \mathrm{O}_{2}$ to $\cdot \mathrm{OH}$ radicals is the key step in CWPO. However, under a basic reaction $\mathrm{pH}$, the generation of hydroxyl radicals was restricted, thereby further decreasing the degradation of BPA [61]. Thus, the change in $\mathrm{pH}$ marginally affects BPA removal.

The adsorption capacity of the Fe catalysts was examined under the severest reaction conditions in this study, i.e., $\mathrm{pH}$ of 3.5 , a reaction temperature of $100{ }^{\circ} \mathrm{C}$, in the absence of the oxidant, and a catalyst concentration of $4 \mathrm{~g} / \mathrm{dm}^{3}$. For Fe/BFS17.5-60 and Fe/BFS30-60, during the $3 \mathrm{~h}$ experiment, $12 \%$ and $17 \%$ of BPA was adsorbed, respectively, revealing that Fe/BFS17.5-60 is catalytically more active than Fe/BFS30-60. The higher adsorption capacity of Fe/BFS30-60 was related to the higher specific surface area of this sample (Table 3).

\subsection{Stability of the Used Catalysts}

The possible leaching of the elements from the prepared AAMs was examined by ICPOES in detail, in addition to the leaching tests (Section 2.1) after oxidation. The oxidized water samples were immediately filtered after $3 \mathrm{~h}$ CWPO using a $0.45 \mu \mathrm{m}$ cellulose nitrate filter to remove the solid catalysts. The $\mathrm{Al}, \mathrm{Si}$, and $\mathrm{Ca}$ concentrations were determined from the oxidized water samples catalyzed by BFS17.5-60, BFS20-60, BFS25-60, and BFS30-60, and in addition to these elements, Fe was analyzed from the filtered samples catalyzed by Fe/BFS17.5-60 and Fe/BFS30-60. According to the results, the leaching of $\mathrm{Ca}$ and $\mathrm{Si}$ was observed under all of the utilized reaction conditions with all catalysts. In all of the oxidized water samples, the Ca concentration was $25-50 \mathrm{mg} / \mathrm{dm}^{3}$, and the Si concentration was $11-19 \mathrm{mg} / \mathrm{dm}^{3}$. However, notably, the Ca concentration was slightly lower in the water samples catalyzed by AAMs without iron. Therefore, the heat treatment of Fe catalysts (Section 3.1) led to the increased dissolution of $\mathrm{Ca}$ in the water phase during oxidation treatment. The leaching of Ca was around the same level as that detected in stability tests (Section 2.1) with BFS17.5-60, BFS20-60, BFS25-60, and BFS30-60, revealing that these samples also can be used at reaction temperatures $>100^{\circ} \mathrm{C}$ and pressures $\geq 2 \mathrm{MPa}$.

The Al concentration of aqueous BPA samples oxidized at the initial $\mathrm{pH}$ was $1.0-1.4 \mathrm{mg} / \mathrm{dm}^{3}$. The dissolution of $\mathrm{Al}$ was slightly higher at $150^{\circ} \mathrm{C}$ and $2.0 \mathrm{MPa}$ (Table 1), i.e., under conditions of the stability test, than that under CWPO reaction conditions. However, in the case of oxidation experiments performed at a $\mathrm{pH}$ of 3.5 , and at temperatures $50^{\circ} \mathrm{C}, 70^{\circ} \mathrm{C}$, and $100^{\circ} \mathrm{C}$ over that of $\mathrm{Fe} / \mathrm{BFS} 17.5-60$ and $\mathrm{Fe} / \mathrm{BFS} 30-60,0.6-1.2 \mathrm{mg} / \mathrm{dm}^{3}$ of $\mathrm{Al}$ was leached from the catalysts in the obtained effluents. Therefore, the dissolution of $\mathrm{Al}$ from the prepared AAMs is more dominant in the CWPO of BPA, which is conducted at the initial $\mathrm{pH}$. Onisei et al. [41] have investigated the leaching behavior of several elements (e.g., $\mathrm{Si}, \mathrm{Pb}, \mathrm{Ca}, \mathrm{Zn}, \mathrm{Al}$ ) from fly ash-based geopolymers. The study was performed in the $\mathrm{pH}$ range of 6-13. According to their results, the leaching of $\mathrm{Al}$ increased slightly in the $\mathrm{pH}$ range of 10.5-13.0. In the CWPO of BPA, the initial $\mathrm{pH}$ of the BPA solution was 6-7. However, at the end of the run, the effluent $\mathrm{pH}$ was $\sim 11$, due to the basic character of the Fe catalysts. Moreover, in CWPO experiments, which were started at a $\mathrm{pH}$ of 3.5, the $\mathrm{pH}$ of the BPA solution was $\sim 10$ in the oxidized water sample. Therefore, the adjustment of 
the $\mathrm{pH}$ at the start of the CWPO of BPA did not considerably affect the removal of BPA, but it decreased the leaching of $\mathrm{Al}$ from the Fe catalysts.

However, the leaching of $\mathrm{Ca}, \mathrm{Si}$, and $\mathrm{Al}$ was not related to the removal of $\mathrm{BPA}$, because those elements were not active in CWPO. The stability of the material is a key characteristic of the catalyst; therefore, the preparation method of AAM-based catalysts should be carefully considered. Moreover, the leaching of iron was rather negligible (maximum of $0.2 \mathrm{mg} / \mathrm{dm}^{3}$ at $70{ }^{\circ} \mathrm{C}$ and at the initial $\mathrm{pH}$ ) using Fe/BFS17.5-60 and Fe/BFS30-60 at the employed reaction temperatures and $\mathrm{pH}$. Therefore, the CWPO of BPA with these catalysts proceeded via a heterogeneous reaction.

The activity and durability in consecutive tests and the effect of heat treatment as a regeneration method were examined using Fe/BFS7.5-60 at $50{ }^{\circ} \mathrm{C}$, at the initial $\mathrm{pH}$, and at $\mathrm{H}_{2} \mathrm{O}_{2}$ and catalyst concentrations of $1.5 \mathrm{~g} / \mathrm{dm}^{3}$ and $4.0 \mathrm{~g} / \mathrm{dm}^{3}$, respectively. To have sufficient material for consecutive tests and regeneration, 12 runs were performed in total, and the catalysts used in these experiments were collected and combined. Between consecutive experiments, the used catalyst was filtered from the effluent and dried at $105^{\circ} \mathrm{C}$ for the subsequent runs.

After the first oxidation reaction, BPA removal of $41 \%$ was observed, which decreased to $\sim 6 \%$ after the second run using the same catalyst (Figure 6 ). Furthermore, BPA removal after the third experiment, which used Fe/BFS17.5-60 twice, was practically the same (34\%) as that observed in the second run, indicative of the catalyst's stability for multiple cycles in the CWPO of BPA. However, the removal of BPA after three cycles using Fe/BFS17.5-60 was around the same as that using BFS17.5-60 for one cycle, revealing that the addition of Fe does not significantly affect catalytic activity due to the basic reaction $\mathrm{pH}$. Moreover, TOC results confirmed the reusability of Fe/BFS17.5-60, while BPA removal was the same during the three consecutive tests.

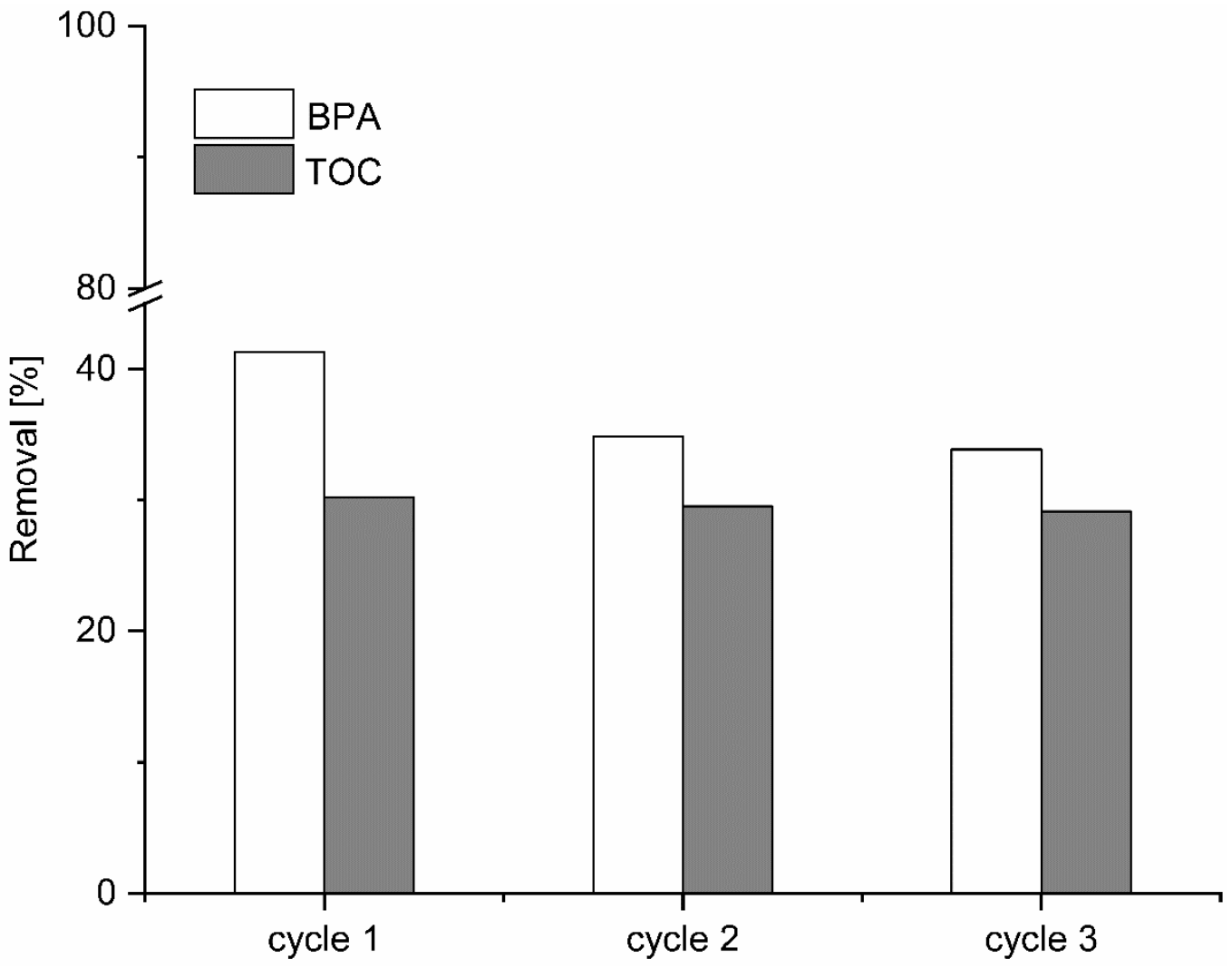

Figure 6. Consecutive tests using Fe/BFS17.5-60 for the CWPO of BPA. Reaction conditions: $c[\mathrm{BPA}]=60 \mathrm{mg} / \mathrm{dm}^{3}$, $c\left[\mathrm{H}_{2} \mathrm{O}_{2}\right]=1.5 \mathrm{~g} / \mathrm{dm}^{3}, c[$ catalyst $]=4 \mathrm{~g} / \mathrm{dm}^{3}, T=50{ }^{\circ} \mathrm{C}$, initial $\mathrm{pH}(6-7)$. 
The regeneration of once-used Fe/BFS17.5-60 was examined by heat treatment at $250{ }^{\circ} \mathrm{C}$ and $500{ }^{\circ} \mathrm{C}$. The procedure was performed by increasing the temperature at a rate of $1{ }^{\circ} \mathrm{C} / \mathrm{min}$ to the reaction temperature, at which the catalyst was kept for $2 \mathrm{~h}$. After oxidation, $34 \%$ and $32 \%$ BPA removal was observed at $250{ }^{\circ} \mathrm{C}$ and $500{ }^{\circ} \mathrm{C}$, respectively, using Fe/BFS17.5-60. Therefore, the regeneration procedure is not effective at returning the activity of the catalysts to the original level. In addition, carbon deposition is confirmed to not be responsible for the activity decrease of Fe/BFS17.5-60, because heat treatment at elevated temperatures is a typical regeneration procedure for catalysts with carbon deactivation [62].

\subsection{Characterization of the Used Catalysts}

Figure 7 shows the X-ray diffractograms of BFS17.5-60, BFS30-60, Fe/BFS17.5-60, and $\mathrm{Fe} / \mathrm{BFS} 30-60$ after oxidation at the initial $\mathrm{pH}$ and at a reaction temperature of $50{ }^{\circ} \mathrm{C}$. According to XRD analysis, the hydrotalcite phase (denoted by \#, ICDD file 00-022-0700) was still present in BFS17.5-60 and BFS30-60, and the $\mathrm{CaCO}_{3}$ phase (a, ICDD file 01-0834609) was observed in all samples. Moreover, in the X-ray diffractograms of Fe/BFS17.5-60 and $\mathrm{Fe} / \mathrm{BFS} 30-60$, the $\mathrm{Fe}_{3} \mathrm{O}_{4}$ and $\mathrm{Fe}_{2} \mathrm{O}_{3}$ iron phases (denoted by +: ICDD file 04-008-8146 and *: ICDD file 04-015-7029, respectively) were still present, but the high Ca concentration of samples led to the overlap of the $\mathrm{CaCO}_{3}$ peaks with those of $\mathrm{Fe}_{3} \mathrm{O}_{4}$ and $\mathrm{Fe}_{2} \mathrm{O}_{3}$ at $2 \theta$ of $36^{\circ}$ and $\mathrm{Fe}_{3} \mathrm{O}_{4}$ at $2 \theta$ of $43^{\circ}$

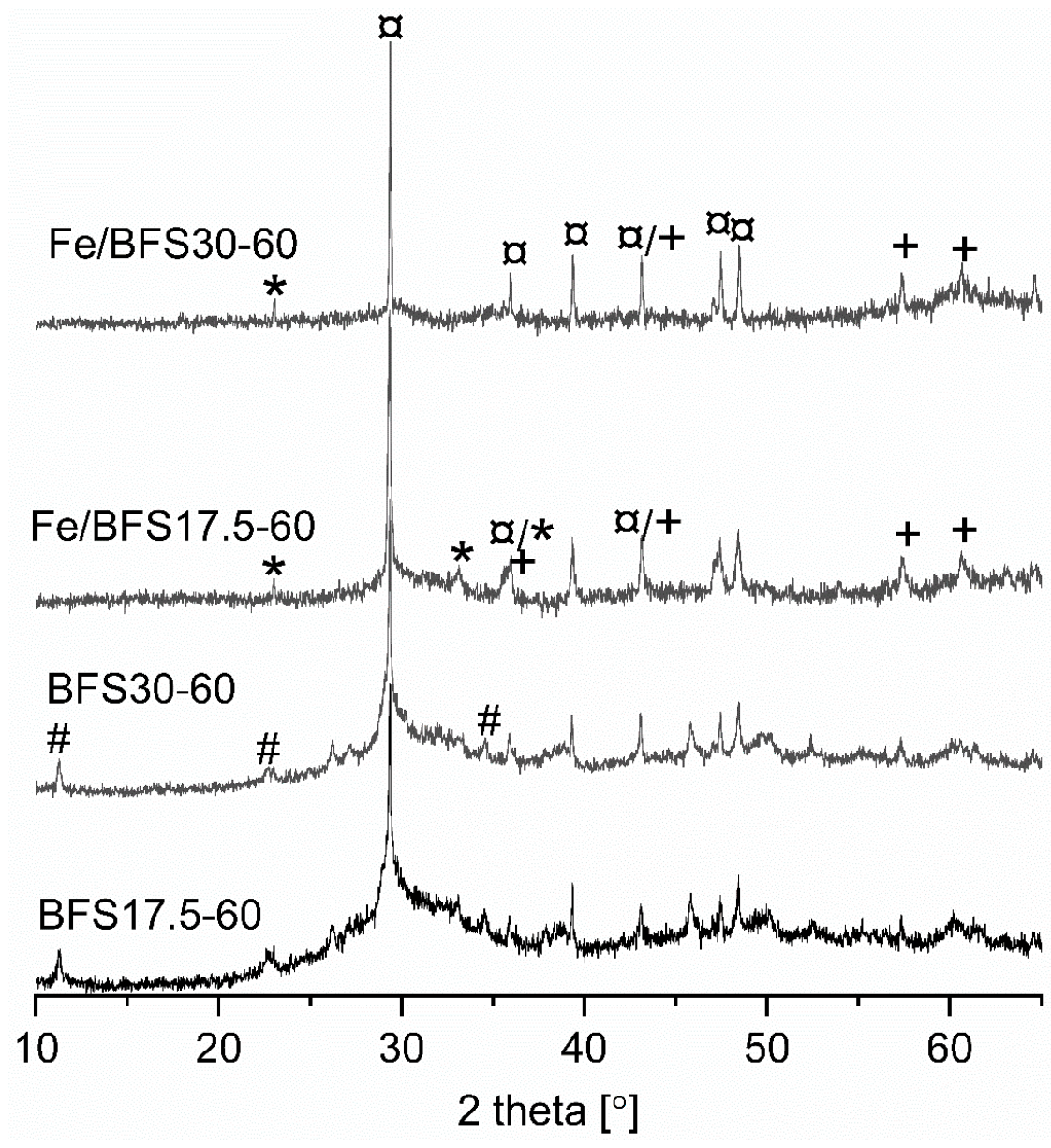

Figure 7. X-ray diffractograms of used BFS17.5-60, BFS30-60, Fe/BFS17.5-60, and Fe/BFS30-60. (\#) ICDD file 00-022-0700 $\left(\mathrm{Mg}_{6} \mathrm{Al}_{2} \mathrm{CO}_{3}(\mathrm{OH})_{16} \cdot 4 \mathrm{H}_{2} \mathrm{O}\right.$, hydrotalcite); (a) ICDD file 01-083-4609 $\left(\mathrm{CaCO}_{3}\right)$; ${ }^{*}$ ) ICDD file 04-015-7029 $\left(\mathrm{Fe}_{2} \mathrm{O}_{3}\right)$; (+) ICDD file 04-008-8146 $\left(\mathrm{Fe}_{3} \mathrm{O}_{4}\right)$. 
Furthermore, acidic $\mathrm{pH}$ and a higher reaction temperature did not affect the phase structure, and hydrotalcite was still observed in the X-ray diffractograms of BFS30-60 and BFS17.5-60 (results not shown).

The specific surface area of samples was analyzed after the oxidation of BPA at the initial $\mathrm{pH}$ and at reaction temperatures of $50^{\circ} \mathrm{C}$ for BFS17.5-60 and BFS30-60, as well as reaction temperatures of $50{ }^{\circ} \mathrm{C}$ and $70{ }^{\circ} \mathrm{C}$ for Fe/BFS17.5-60 and Fe/BFS30-60. The BET results for used BFS17.5-60 and BFS30-60 revealed that the specific surface areas were 10.4 and $18.5 \mathrm{~m}^{2} / \mathrm{g}$, respectively, revealing that the surface area of BFS30-60 decreases to $\sim 30 \%$, while a rather negligible change in the surface area of BFS17.5-60 was observed (Table 3). For Fe catalysts, the specific surface areas increased after oxidation. In case of Fe/BFS17.560 , the surface area was $\sim 45 \%$ higher, and in case of Fe/BFS30-60, it doubled compared to that of the fresh catalyst (Table 3). Clearly, during oxidation, the Fe catalyst surface is refined by $\mathrm{H}_{2} \mathrm{O}_{2}$. For example, Han et al. [63] and Liu et al. [64] have used hydrogen peroxide to modify surface properties, i.e., to increase the surface area and porosity of materials. However, the larger specific surface area did not improve the removal of BPA in consecutive tests using Fe/BFS17.5-60 (Figure 6); therefore, the CWPO of BPA is not a surface area-specific reaction, as is the case for the catalytic wet air oxidation of BPA [65].

\section{Materials and Methods}

In this section, the preparation method and characterization techniques of catalysts are described. In addition, reaction conditions for the CWPO of the bisphenol A aqueous solution are presented.

\subsection{Preparation of Alkali-Activated Materials and Fe Catalysts}

AAMs were synthesized using powdered blast furnace slag (BFS) obtained from the Finnish steel industry. Table 5 lists the elemental composition of the slag, as determined by ICP-OES analysis.

AAMs were prepared by mixing $40 \mathrm{~g}$ of BFS with $17.5,20.0,25.0$, and $30.0 \mathrm{~g}$ of $50 \mathrm{wt} \%$ sodium hydroxide $(\mathrm{NaOH} \geq 97 \%$, Merck, Darmsdtadt, Germany). The formed pastes were poured into molds, followed by consolidation in plastic bags at room temperature for $168 \mathrm{~h}$. For comparison, consolidation was first performed at $60{ }^{\circ} \mathrm{C}$ for $24 \mathrm{~h}$ and then for $144 \mathrm{~h}$ at room temperature. The prepared samples were named according to their $\mathrm{NaOH}$ concentration and consolidation temperature (Table 6). Before use, the materials were crushed using a jaw crusher, sieved to a particle size of $0.5-2.0 \mathrm{~mm}$, and washed with de-ionized water. As the active metal, Fe was impregnated on the AAMs by ion exchange. First, $5 \mathrm{~g}$ of AAM and $0.5 \mathrm{dm}^{3}$ of $0.01 \mathrm{M}\left(\mathrm{NH}_{4}\right)_{2} \mathrm{Fe}\left(\mathrm{SO}_{4}\right)_{2}(99.0-101.5 \%$, Merck, Darmsdtadt, Germany) were mixed in a sand bath and left overnight at $80^{\circ} \mathrm{C}$. The solids were collected by filtration, washed with deionized water, and dried overnight at $120^{\circ} \mathrm{C}$. Finally, the prepared Fe catalysts were subjected to calcination at $500{ }^{\circ} \mathrm{C}$ for $2 \mathrm{~h}$, increasing the temperature from room temperature to the target temperature at a rate of $1{ }^{\circ} \mathrm{C} / \mathrm{min}$.

Table 6. Abbreviations of the prepared AAMs and Fe catalysts. Samples were named according to their $\mathrm{NaOH}$ concentrations and curing temperatures.

\begin{tabular}{cccc}
\hline Studied Samples & $\mathbf{5 0} \mathbf{~ w t} \mathbf{~} \mathbf{~ N a O H}[\mathbf{g}]$ & Consolidation $\mathbf{T}\left[{ }^{\circ} \mathbf{C}\right]$ & Si/Na Ratio \\
\hline BFS17.5-20 & 17.5 & 20 & 3.24 \\
BFS17.5-60 & 17.5 & 60 & 3.24 \\
BFS20-20 & 20.0 & 20 & 2.84 \\
BFS20-60 & 20.0 & 60 & 2.84 \\
BFS25-20 & 25.0 & 20 & 2.27 \\
BFS25-60 & 25.0 & 60 & 2.27 \\
BFS30-20 & 30.0 & 20 & 1.89 \\
BFS30-60 & 30.0 & 60 & 1.89 \\
Fe/BFS17.5-60 & 17.0 & 60 & 3.24 \\
Fe/BFS30-60 & 30.0 & 60 & 2.84 \\
\hline
\end{tabular}




\subsection{Stability of AAMs}

The stability of as-prepared AAMs was examined by measuring the possible leaching of the main elements of samples (i.e., $\mathrm{Al}, \mathrm{Ca}, \mathrm{Mg}, \mathrm{Na}$, and $\mathrm{Si}$ ) to the water phase. Before the test, samples were crushed using a jaw crusher, sieved to a particle size of 1-2 mm, washed with deionized water, and dried. Stability tests were performed in a pressurized reactor at $150{ }^{\circ} \mathrm{C}$ and under a nitrogen atmosphere of $2 \mathrm{MPa}$. The crushed AAMs at a concentration of $4 \mathrm{~g} / \mathrm{dm}^{3}$ were continuously stirred for $4 \mathrm{~h}$ with $0.16 \mathrm{dm}^{3}$ of deionized water. The ready leaching of elements was detected by conductivity measurement during and after the test, while the possible dissolution of $\mathrm{Al}, \mathrm{Ca}, \mathrm{Mg}$, Na, and $\mathrm{Si}$ was analyzed by inductively coupled plasma-optical emission spectroscopy (ICP-OES, Thermo Electron iCAP 6500 Duo, Thermo Fisher Scientific, Waltham, MA, USA).

\subsection{Characterization of Samples}

The surface morphology and chemical composition of the prepared AAMs were analyzed by field emission scanning electron microscopy (FESEM; Carl Zeiss Microscopy $\mathrm{GMbH}$, Jena, Germany) combined with energy-dispersive X-ray spectroscopy (EDS; analyzer at the Centre for Material Analysis, University of Oulu, Finland). The phase composition of AAMs was determined by powder X-ray diffraction (XRD) with a PANalytical $X^{\prime}$ Pert Pro X-ray diffractometer (Malvern PANalytical, Almelo, The Netherlands). XRD analysis was performed by scanning two theta values between $10^{\circ}$ and $70^{\circ}$ with monochromatic $\mathrm{Cu} \mathrm{K} \alpha 1(\lambda=1.5406 \AA)$ at $45 \mathrm{kV}$ and $40 \mathrm{~mA}$ at a scan speed of $0.021^{\circ} / \mathrm{s}$. Crystalline phases were identified by HighScore Plus software using the Powder Diffraction File standards from the International Centre for Diffraction DATA ICDD (PDF-4+ 2020 RDB). Diffuse-reflectance infrared Fourier transform spectroscopy (DRIFTS) was employed to investigate the degree of polymerization of the prepared samples. DRIFT spectra were recorded on a Bruker PMA 50 Vertex $80 \mathrm{~V}$ (Bruker, Billerica, MA, USA), equipped with a Harrick Praying Mantis diffuse reflection accessory and a high-temperature reaction chamber, by baseline measurement using $\mathrm{KBr}$. Before analysis, the sample chamber was flushed with nitrogen $\left(100 \mathrm{~cm}^{3} / \mathrm{min}\right)$, heated at a rate of $10^{\circ} \mathrm{C} / \mathrm{min}$ to the target temperature of $120^{\circ} \mathrm{C}$, and maintained at that temperature for $30 \mathrm{~min}$. Measurements were conducted at $400-4000 \mathrm{~cm}^{-1}$ with a resolution of $4 \mathrm{~cm}^{-1}$ and 500 scans per minute. The specific surface areas and porosity were obtained from nitrogen adsorption-desorption isotherms at the liquid nitrogen temperature $\left(-196^{\circ} \mathrm{C}\right)$ by the Brunauer-Emmett-Teller (BET) method on a Micromeritics ASAP 2020 system (Micromeritics Instrument Corporation, Norcross, GA, USA). The pore size distribution was calculated by density functional theory (DFT) [66]. Furthermore, the main elements of the prepared samples ( $\mathrm{Al}, \mathrm{Ca}, \mathrm{Mg}, \mathrm{Na}$, and $\mathrm{Si}$ ) and the active metal Fe were analyzed by ICP-OES analysis (Thermo Electron iCAP 6500 Duo, Thermo Fisher Scientific, Waltham, MA, USA).

\subsection{Catalytic Wet Peroxide Oxidation Experiments}

Oxidation experiments with a BPA aqueous solution $(60 \mathrm{mg} / \mathrm{L})$ were performed in a three-necked flask equipped with a reflux condenser. BFS30-60, BFS25-60, BFS20-60, BFS17.5-60, Fe/BFS30-60, and Fe/BFS17.5-60 were examined at a reaction temperature of $50{ }^{\circ} \mathrm{C}$, a $\mathrm{H}_{2} \mathrm{O}_{2}$ concentration of $1.5 \mathrm{~g} / \mathrm{dm}^{3}$ (stoichiometric amount to total oxidation of BPA), and a catalyst loading of $4 \mathrm{~g} / \mathrm{dm}^{3}$, with a reaction volume of $0.16 \mathrm{dm}^{3}$. Oxidation was started while the reaction temperature was reached by the addition of $\mathrm{H}_{2} \mathrm{O}_{2}$, which was added in batches to maintain a stable oxidation agent concentration during the $3 \mathrm{~h}$ test. Water samples were taken as a function of reaction time, which were filtered using a $0.45 \mu \mathrm{m}$ filter paper. The $\mathrm{pH}$ and dissolved oxygen (DO) were measured from water samples during the experiment. Furthermore, the effects of $\mathrm{pH}$ and temperature on oxidation were examined using Fe/BFS30-60 and Fe/BFS17.5-60. For evaluating the stability and reusability of the prepared materials, Fe/BFS17.5-60 was examined in three consecutive oxidation reactions. In addition, the regeneration of used Fe/BFS17.5-60 was 
performed by heating the catalyst for $2 \mathrm{~h}$ at two temperatures (i.e., $250{ }^{\circ} \mathrm{C}$ and $500{ }^{\circ} \mathrm{C}$ ) to examine the effect of heat treatment on the activity of the used catalyst.

\subsection{Water Sample Analysis}

The BPA concentration of the water samples was determined by high-pressure liquid chromatography (HPLC) equipped with a Waters 996 photodiode array (PDA) detector (Waters Corp., Milford, MA, USA) at a wavelength of $226 \mathrm{~nm}$. A mixture of $0.1 \%$ trifluoracetic acid (TFA) in methanol and $0.1 \%$ TFA in water at a flow rate of $0.4 \mathrm{~cm}^{3} / \mathrm{min}$ was used as the eluent mixture to separate compounds on a SunFireTM C18 5-m $2.1 \times 100 \mathrm{~mm}$ column (Waters Corp., Milford, MA, USA) operated at $30{ }^{\circ} \mathrm{C}$. The total organic carbon (TOC) concentration of water samples was determined from the initial and final samples on a Skalar FormacsHT Total Organic Carbon/total nitrogen analyzer (Breda, The Netherlands). Possible leaching of $\mathrm{Al}, \mathrm{Ca}, \mathrm{Mg}, \mathrm{Na}$, and $\mathrm{Si}$ was analyzed from the final samples after oxidation by ICP-OES analysis (Thermo Electron iCAP 6500 Duo, Thermo Fisher Scientific, Waltham, MA, USA).

\section{Conclusions}

In this study, novel, eco-efficient, BFS-based alkali-activated materials were prepared and examined as catalysts for the CWPO of a BPA aqueous solution. AAMs consolidated at $60{ }^{\circ} \mathrm{C}$ were selected for catalytic studies, as they were more stable in the aqueous phase, and the phase structure was more porous than that of the samples cured at room temperature. BFSXX-60 samples exhibited moderate activity for the CWPO of BPA at $50^{\circ} \mathrm{C}$ and at the initial $\mathrm{pH}$. The catalytic activities of Fe/BFS17.5-60 and Fe/BFS30-60 were examined at reaction temperatures of $50{ }^{\circ} \mathrm{C}, 70^{\circ} \mathrm{C}$, and $100{ }^{\circ} \mathrm{C}$, and at the initial $\mathrm{pH}$ and a pH of 3.5. The addition of iron to the BFS-based materials led to the increased removal of BPA, with the highest BPA removal (50\%) achieved using Fe/BFS30-60 at a pH of 3.5 at $70{ }^{\circ} \mathrm{C}$. Furthermore, Fe/BFS17.5-60 exhibited moderate activity, even after three consecutive tests, and no change in the phase structure of the AAMS after the oxidation reaction was observed. Although prepared AAMs are interesting alternatives for catalytic water-phase applications, dissolution of $\mathrm{Ca}$ and $\mathrm{Si}$, as well as small amounts of $\mathrm{Al}$, was observed from AAMs during oxidation. In addition, the basic character of the material prevented higher removal of BPA. Therefore, additional attention should be focused on the stability and surface $\mathrm{pH}$ (e.g., pretreatment with acid) of AAMs in our future studies.

Author Contributions: Methodology, A.H. and J.P.; software, A.H; investigation, A.H. and T.H.; data curation, A.H.; writing-original draft preparation, A.H.; writing-review and editing, all authors; visualization, A.H.; project administration, U.L.; funding acquisition, U.L. and A.H. All authors have read and agreed to the published version of the manuscript.

Funding: This work was partly funded by the Renlund Foundation, within the project "New catalyst materials for wastewater treatment from industrial side streams".

Data Availability Statement: The data presented in this study are available within the article (tables and figures). The data presented in this study are available on request from the corresponding author.

Acknowledgments: Financial support from Renlund Foundation is gratefully acknowledged. Henrik Romar, Katariina Hautamäki, Tiina Leskelä, Ilkka Vesavaara, Jere Taipalus, Eemeli Koskela, Santeri Impiö, and Carlos Gonzales are acknowledged.

Conflicts of Interest: The authors declare no conflict of interest. The funders had no role in the design of the study; in the collection, analyses, or interpretation of data; in the writing of the manuscript, or in the decision to publish the results. 


$\begin{array}{ll}\text { Abbreviations } \\ \text { AAM } & \text { Alkali-activated material } \\ \text { AOP } & \text { Advanced oxidation process } \\ \text { BET } & \text { Brunauer-Emmett-Teller } \\ \text { BFS } & \text { Blast furnace slag } \\ \text { BPA } & \text { Bisphenol A } \\ \text { CWPO } & \text { Catalytic wet peroxide oxidation } \\ \text { DFT } & \text { Density functional theory } \\ \text { DO } & \text { Dissolved oxygen } \\ \text { DRIFTS } & \text { Diffuse-reflectance infrared Fourier transform spectroscopy } \\ \text { Fe/BFS30-60 } & \text { Iron-containing blast furnace slag-based catalyst } \\ \text { FESEM-EDS } & \text { Field emission scanning electron microscope with energy-dispersive } \\ & \text { X-ray spectroscopy } \\ \text { FTIR } & \text { Fourier transform infrared spectroscopy } \\ \text { HPLC } & \text { High-pressure liquid chromatography } \\ \text { ICDD } & \text { International Centre for Diffraction Data } \\ \text { ICP-OES } & \text { Inductively coupled plasma-optical emission spectroscopy } \\ \text { IR } & \text { Infrared } \\ \text { PDA } & \text { Photodiode array } \\ \text { PV } & \text { Pore volume } \\ \text { SSA } & \text { Specific surface areas } \\ \text { TFA } & \text { Trifluoracetic acid } \\ \text { TOC } & \text { Total organic carbon } \\ \text { UV } & \text { Ultraviolet } \\ \text { XRD } & \text { X-ray diffraction } \\ \end{array}$

\section{References}

1. Provis, J.L.; Van Deventer, J.S.J. 1-Introduction to geopolymers. Geopolymers 2009, 1-11. [CrossRef]

2. Bernal, S.A.; Provis, J.L.; Fernández-Jiménez, A.; Krivenko, P.V.; Kavalerova, E.; Palacios, M.; Shi, C. Binder Chemistry—HighCalcium Alkali-Activated Materials. In Alkali Activated Materials: State-of-the-Art Report, RILEM TC 224-AAM; Provis, J.L., van Deventer, J.S.J., Eds.; Springer: Dordrecht, The Netherlands, 2014; pp. 59-91.

3. Duxson, P.; Fernández-Jiménez, A.; Provis, J.L.; Lukey, G.C.; Palomo, A.; van Deventer, J.S.J. Geopolymer technology: The current state of the art. J. Mater. Sci. 2007, 42, 2917-2933. [CrossRef]

4. Davidovits, J. Geopolymers. J. Therm. Anal. 1991, 37, 1633-1656. [CrossRef]

5. Medpelli, D.; Seo, J.; Seo, D. Geopolymer with Hierarchically Meso-/Macroporous Structures from Reactive Emulsion Templating. J. Am. Ceram. Soc. 2014, 97, 70-73. [CrossRef]

6. Luukkonen, T.; Sarkkinen, M.; Kemppainen, K.; Rämö, J.; Lassi, U. Metakaolin geopolymer characterization and application for ammonium removal from model solutions and landfill leachate. Appl. Clay. Sci. 2016, 119, 266-276. [CrossRef]

7. Luukkonen, T.; Runtti, H.; Niskanen, M.; Tolonen, E.; Sarkkinen, M.; Kemppainen, K.; Rämö, J.; Lassi, U. Simultaneous removal of $\mathrm{Ni}(\mathrm{II}), \mathrm{As}(\mathrm{III})$, and $\mathrm{Sb}(\mathrm{III})$ from spiked mine effluent with metakaolin and blast-furnace-slag geopolymers. J. Environ. Manag. 2016, 166, 579-588. [CrossRef]

8. Khan, M.I.; Min, T.K.; Azizli, K.; Sufian, S.; Ullah, H.; Man, Z. Effective removal of methylene blue from water using phosphoric acid based geopolymers: Synthesis, characterizations and adsorption studies. RSC Adv. 2015, 5, 61410-61420. [CrossRef]

9. Yousef, R.I.; El-Eswed, B.; Alshaaer, M.; Khalili, F.; Khoury, H. The influence of using Jordanian natural zeolite on the adsorption, physical, and mechanical properties of geopolymers products. J. Hazard. Mater. 2009, 165, 379-387. [CrossRef]

10. Sazama, P.; Bortnovsky, O.; Dědeček, J.; Tvarůžková, Z.; Sobalík, Z. Geopolymer based catalysts-New group of catalytic materials. Catal. Today 2011, 164, 92-99. [CrossRef]

11. Mejía de Gutiérrez, R.; Villaquirán-Caicedo, M.A.; Guzmán-Aponte, L.A. Alkali-activated metakaolin mortars using glass waste as fine aggregate: Mechanical and photocatalytic properties. Constr. Build. Mater. 2020, 235, 117510. [CrossRef]

12. Kang, L.; Zhang, Y.J.; Zhang, L.; Zhang, K. Preparation, characterization and photocatalytic activity of novel CeO2 loaded porous alkali-activated steel slag-based binding material. Int. J. Hydrog. Energy 2017, 42, 17341-17349. [CrossRef]

13. Sharma, S.; Medpelli, D.; Chen, S.; Seo, D. Calcium-modified hierarchically porous aluminosilicate geopolymer as a highly efficient regenerable catalyst for biodiesel production. RSC Adv. 2015, 5, 65454-65461. [CrossRef]

14. Guerra, P.; Kim, M.; Teslic, S.; Alaee, M.; Smyth, S.A. Bisphenol-A removal in various wastewater treatment processes: Operational conditions, mass balance, and optimization. J. Environ. Manag. 2015, 152, 192-200. [CrossRef] [PubMed]

15. Kitamura, S.; Suzuki, T.; Sanoh, S.; Kohta, R.; Jinno, N.; Sugihara, K.; Yoshihara, S.; Fujimoto, N.; Watanabe, H.; Ohta, S. Comparative Study of the Endocrine-Disrupting Activity of Bisphenol A and 19 Related Compounds. Toxicol. Sci. 2005, 84, 249-259. [CrossRef] [PubMed] 
16. Melcer, H.; Klečka, G. Treatment of Wastewaters Containing Bisphenol A: State of the Science Review. Water Environ. Res. 2011, 83, 650-666. [CrossRef] [PubMed]

17. Chen, J.; Huang, X.; Lee, D. Bisphenol A removal by a membrane bioreactor. Process. Biochem. 2008, 43, 451-456. [CrossRef]

18. Shabtai, I.A.; Mishael, Y.G. Polycyclodextrin-Clay Composites: Regenerable Dual-Site Sorbents for Bisphenol A Removal from Treated Wastewater. ACS Appl. Mater. Interfaces 2018, 10, 27088-27097. [CrossRef] [PubMed]

19. Juhola, R.; Heponiemi, A.; Tuomikoski, S.; Hu, T.; Vielma, T.; Lassi, U. Preparation of Novel Fe Catalysts from Industrial By-Products: Catalytic Wet Peroxide Oxidation of Bisphenol A. Top. Catal. 2017, 60, 1387-1400. [CrossRef]

20. Salimi, M.; Esrafili, A.; Gholami, M.; Jonidi Jafari, A.; Rezaei Kalantary, R.; Farzadkia, M.; Kermani, M.; Sobhi, H.R. Contaminants of emerging concern: A review of new approach in AOP technologies. Environ. Monit. Assess. 2017, 189, 414. [CrossRef]

21. Kovačič, A.; Česen, M.; Laimou-Geraniou, M.; Lambropoulou, D.; Kosjek, T.; Heath, D.; Heath, E. Stability, biological treatment and UV photolysis of 18 bisphenols under laboratory conditions. Environ. Res. 2019, 179, 108738. [CrossRef]

22. Umar, M.; Roddick, F.; Fan, L.; Aziz, H.A. Application of ozone for the removal of bisphenol A from water and wastewater-A review. Chemosphere 2013, 90, 2197-2207. [CrossRef] [PubMed]

23. Sharma, J.; Mishra, I.M.; Kumar, V. Degradation and mineralization of Bisphenol A (BPA) in aqueous solution using advanced oxidation processes: UV/H2O2 and UV/S2O82- oxidation systems. J. Environ. Manag. 2015, 156, 266-275. [CrossRef] [PubMed]

24. Dudziak, M.; Burdzik, E. Oxidation of bisphenol A from simulated and real urban wastewater effluents by UV, O3 and UV/O3. Null 2016, 57, 1075-1083. [CrossRef]

25. Jia, C.; Wang, Y.; Zhang, C.; Qin, Q.; Kong, S.; Kouakou Yao, S. Photocatalytic Degradation of Bisphenol A in Aqueous Suspensions of Titanium Dioxide. Environ. Eng. Sci. 2012, 29, 630-637. [CrossRef]

26. Ahmadi, M.; Rahmani, H.; Takdastan, A.; Jaafarzadeh, N.; Mostoufi, A. A novel catalytic process for degradation of bisphenol A from aqueous solutions: A synergistic effect of nano-Fe3O4@Alg-Fe on O3/H2O2. Process. Saf. Environ. Prot. 2016, 104, 413-421. [CrossRef]

27. Perathoner, S.; Centi, G. Wet hydrogen peroxide catalytic oxidation (WHPCO) of organic waste in agro-food and industrial streams. Top. Catal. 2005, 33, 207-224. [CrossRef]

28. Tu, Y.; Tian, S.; Kong, L.; Xiong, Y. Co-catalytic effect of sewage sludge-derived char as the support of Fenton-like catalyst. Chem. Eng. J. 2012, 185-186, 44-51. [CrossRef]

29. Messele, S.A.; Soares, O.S.G.P.; Órfão, J.J.M.; Stüber, F.; Bengoa, C.; Fortuny, A.; Fabregat, A.; Font, J. Zero-valent iron supported on nitrogen-containing activated carbon for catalytic wet peroxide oxidation of phenol. Appl. Catal. B Environ. 2014, 154-155, 329-338. [CrossRef]

30. Dehkordi, A.M.; Ebrahimi, A.A. Catalytic Wet Peroxide Oxidation of Phenol in a New Two-Impinging-Jets Reactor. Ind. Eng. Chem. Res. 2009, 48, 10619-10626. [CrossRef]

31. Domínguez, C.M.; Ocón, P.; Quintanilla, A.; Casas, J.A.; Rodriguez, J.J. Graphite and carbon black materials as catalysts for wet peroxide oxidation. Appl. Catal. B Environ. 2014, 144, 599-606. [CrossRef]

32. Martin-Martinez, M.; Machado, B.F.; Serp, P.; Morales-Torres, S.; Silva, A.M.T.; Figueiredo, J.L.; Faria, J.L.; Gomes, H.T. Carbon nanotubes as catalysts for wet peroxide oxidation: The effect of surface chemistry. Catal. Today 2020, 357, 332-340. [CrossRef]

33. Juhola, R.; Heponiemi, A.; Tuomikoski, S.; Hu, T.; Prokkola, H.; Romar, H.; Lassi, U. Biomass-based composite catalysts for catalytic wet peroxide oxidation of bisphenol A: Preparation and characterization studies. J. Environ. Chem. Eng. $2019,7,103127$. [CrossRef]

34. Yan, Y.; Jiang, S.; Zhang, H.; Zhang, X. Preparation of novel Fe-ZSM-5 zeolite membrane catalysts for catalytic wet peroxide oxidation of phenol in a membrane reactor. Chem. Eng. J. 2015, 259, 243-251. [CrossRef]

35. Valkaj, K.M.; Katović, A.; Zrnčević, S. Catalytic Properties of Cu/13X Zeolite Based Catalyst in Catalytic Wet Peroxide Oxidation of Phenol. Ind. Eng. Chem. Res. 2011, 50, 4390-4397. [CrossRef]

36. Galeano, L.A.; Gil, A.; Vicente, M.A. Effect of the atomic active metal ratio in $\mathrm{Al} / \mathrm{Fe}-, \mathrm{Al} / \mathrm{Cu}-$ and $\mathrm{Al} /(\mathrm{Fe}-\mathrm{Cu})$-intercalating solutions on the physicochemical properties and catalytic activity of pillared clays in the CWPO of methyl orange. Appl. Catal. B Environ. 2010, 100, 271-281. [CrossRef]

37. Garrido-Ramirez, E.G.; Sivaiah, M.V.; Barrault, J.; Valange, S.; Theng, B.K.G.; Ureta-Zañartu, M.S.; Mora, M.d.1.L. Catalytic wet peroxide oxidation of phenol over iron or copper oxide-supported allophane clay materials: Influence of catalyst $\mathrm{SiO} 2 / \mathrm{Al} 2 \mathrm{O} 3$ ratio. Microporous Mesoporous Mater. 2012, 162, 189-198. [CrossRef]

38. Li, C.; He, Y.; Tang, Q.; Wang, K.; Cui, X. Study of the preparation of CdS on the surface of geopolymer spheres and photocatalyst performance. Mater. Chem. Phys. 2016, 178, 204-210. [CrossRef]

39. Fallah, M.; MacKenzie, K.J.D.; Hanna, J.V.; Page, S.J. Novel photoactive inorganic polymer composites of inorganic polymers with copper(I) oxide nanoparticles. J. Mater. Sci. 2015, 50, 7374-7383. [CrossRef]

40. Falah, M.; MacKenzie, K.J.D.; Knibbe, R.; Page, S.J.; Hanna, J.V. New composites of nanoparticle Cu (I) oxide and titania in a novel inorganic polymer (geopolymer) matrix for destruction of dyes and hazardous organic pollutants. J. Hazard. Mater. 2016, 318, 772-782. [CrossRef]

41. Onisei, S.; Pontikes, Y.; Van Gerven, T.; Angelopoulos, G.N.; Velea, T.; Predica, V.; Moldovan, P. Synthesis of inorganic polymers using fly ash and primary lead slag. J. Hazard. Mater. 2012, 205-206, 101-110. [CrossRef] [PubMed] 
42. Muñiz-Villarreal, M.S.; Manzano-Ramírez, A.; Sampieri-Bulbarela, S.; Gasca-Tirado, J.R.; Reyes-Araiza, J.L.; Rubio-Ávalos, J.C.; Pérez-Bueno, J.J.; Apatiga, L.M.; Zaldivar-Cadena, A.; Amigó-Borrás, V. The effect of temperature on the geopolymerization process of a metakaolin-based geopolymer. Mater. Lett. 2011, 65, 995-998. [CrossRef]

43. Sindhunata; van Deventer, J.S.J.; Lukey, G.C.; Xu, H. Effect of Curing Temperature and Silicate Concentration on Fly-Ash-Based Geopolymerization. Ind. Eng. Chem. Res. 2006, 45, 3559-3568. [CrossRef]

44. Roelofs, J.C.A.A.; Lensveld, D.J.; van Dillen, A.J.; de Jong, K.P. On the Structure of Activated Hydrotalcites as Solid Base Catalysts for Liquid-Phase Aldol Condensation. J. Catal. 2001, 203, 184-191. [CrossRef]

45. Alzeer, M.I.M.; MacKenzie, K.J.D.; Keyzers, R.A. Porous aluminosilicate inorganic polymers (geopolymers): A new class of environmentally benign heterogeneous solid acid catalysts. Appl. Catal. A Gen. 2016, 524, 173-181. [CrossRef]

46. Mozgawa, W.; Deja, J. Spectroscopic studies of alkaline activated slag geopolymers. J. Mol. Struct. 2009, 924-926, 434-441. [CrossRef]

47. Heinrich, F.; Schmidt, C.; Löffler, E.; Menzel, M.; Grünert, W. Fe-ZSM-5 Catalysts for the Selective Reduction of NO by Isobutane-The Problem of the Active Sites. J. Catal. 2002, 212, 157-172. [CrossRef]

48. Waijarean, N.; MacKenzie, K.J.D.; Asavapisit, S.; Piyaphanuwat, R.; Jameson, G.N.L. Synthesis and properties of geopolymers based on water treatment residue and their immobilization of some heavy metals. J. Mater. Sci. 2017, 52, 7345-7359. [CrossRef]

49. Gabrienko, A.A.; Danilova, I.G.; Arzumanov, S.S.; Toktarev, A.V.; Freude, D.; Stepanov, A.G. Strong acidity of silanol groups of zeolite beta: Evidence from the studies by IR spectroscopy of adsorbed CO and 1H MAS NMR. Microporous Mesoporous Mater. 2010, 131, 210-216. [CrossRef]

50. Sahu, P.K. A green approach to the synthesis of a nano catalyst and the role of basicity, calcination, catalytic activity and aging in the green synthesis of 2-aryl bezimidazoles, benzothiazoles and benzoxazoles. RSC Adv. 2017, 7, 42000-42012. [CrossRef]

51. Mao, W.; Ma, H.; Wang, B. A clean method for solvent-free nitration of toluene over sulfated titania promoted by ceria catalysts. J. Hazard. Mater. 2009, 167, 707-712. [CrossRef]

52. Yunsheng, Z.; Wei, S.; Qianli, C.; Lin, C. Synthesis and heavy metal immobilization behaviors of slag based geopolymer. J. Hazard. Mater. 2007, 143, 206-213. [CrossRef] [PubMed]

53. Lee, W.K.W.; van Deventer, J.S.J. Use of Infrared Spectroscopy to Study Geopolymerization of Heterogeneous Amorphous Aluminosilicates. Langmuir 2003, 19, 8726-8734. [CrossRef]

54. Lei, Y.; Huo, J.; Liao, H. Fabrication and catalytic mechanism study of CeO2-Fe2O3-ZnO mixed oxides on double surfaces of polyimide substrate using ion-exchange technique. Mater. Sci. Semicond. Process. 2018, 74, 154-164. [CrossRef]

55. Lei, Y.; Huo, J.; Liao, H. Microstructure and photocatalytic properties of polyimide/heterostructured NiO-Fe2O3-ZnO nanocomposite films via an ion-exchange technique. RSC Adv. 2017, 7, 40621-40631. [CrossRef]

56. Lu, L.; Li, J.; Ng, D.H.L.; Yang, P.; Song, P.; Zuo, M. Synthesis of novel hierarchically porous Fe3O4@MgAl-LDH magnetic microspheres and its superb adsorption properties of dye from water. J. Ind. Eng. Chem. 2017, 46, 315-323. [CrossRef]

57. Fajerwerg, K.; Debellefontaine, H. Wet oxidation of phenol by hydrogen peroxide using heterogeneous catalysis Fe-ZSM-5: A promising catalyst. Appl. Catal. B Environ. 1996, 10, L229-L235. [CrossRef]

58. Centi, G.; Perathoner, S.; Torre, T.; Verduna, M.G. Catalytic wet oxidation with $\mathrm{H} 2 \mathrm{O} 2$ of carboxylic acids on homogeneous and heterogeneous Fenton-type catalysts. Catal. Today 2000, 55, 61-69. [CrossRef]

59. Yan, Y.; Jiang, S.; Zhang, H. Catalytic wet oxidation of phenol with Fe-ZSM-5 catalysts. RSC Adv. 2016, 6, 3850-3859. [CrossRef]

60. Arnold, S.M.; Hickey, W.J.; Harris, R.F. Degradation of Atrazine by Fenton's Reagent: Condition Optimization and Product Quantification. Environ. Sci. Technol. 1995, 29, 2083-2089. [CrossRef]

61. Hua, Z.; Ma, W.; Bai, X.; Feng, R.; Yu, L.; Zhang, X.; Dai, Z. Heterogeneous Fenton degradation of bisphenol A catalyzed by efficient adsorptive Fe3O4/GO nanocomposites. Environ. Sci. Pollut. Res. 2014, 21, 7737-7745. [CrossRef]

62. Argyle, M.D.; Bartholomew, C.H. Heterogeneous Catalyst Deactivation and Regeneration: A Review. Catalysts 2015, 5, 145-269. [CrossRef]

63. Han, E.; Vijayarangamuthu, K.; Youn, J.; Park, Y.; Jung, S.; Jeon, K. Degussa P25 TiO2 modified with H2O2 under microwave treatment to enhance photocatalytic properties. Catal. Today 2018, 303, 305-312. [CrossRef]

64. Liu, J.; Xiong, Z.; Zhou, F.; Lu, W.; Jin, J.; Ding, S. Promotional effect of H2O2 modification on the cerium-tungsten-titanium mixed oxide catalyst for selective catalytic reduction of NO with NH3. J. Phys. Chem. Solids 2018, 121, 360-366. [CrossRef]

65. Heponiemi, A.; Azalim, S.; Hu, T.; Vielma, T.; Lassi, U. Efficient removal of bisphenol A from wastewaters: Catalytic wet air oxidation with Pt catalysts supported on Ce and Ce-Ti mixed oxides. AIMS Mater. Sci. 2019, 6, 25-44. [CrossRef]

66. Seaton, N.A.; Walton, J.P.R.B.; quirke, N. A new analysis method for the determination of the pore size distribution of porous carbons from nitrogen adsorption measurements. Carbon 1989, 27, 853-861. [CrossRef] 